\title{
International trade in GMOs: have markets paid premiums on Brazilian soybeans?
}

\author{
Comércio Internacional de OGMs: Os importadores pagaram prêmios pela \\ soja brasileira?
}

Paulo Ricardo Silva Oliveira ${ }^{1}$ (1) , José Maria Ferreira Jardim da Silveira ${ }^{2}$ (1), Marcelo Marques de Magalhães ${ }^{3}$ (1) , Roney Fraga Souza ${ }^{4}$ (1)

${ }^{1}$ Pontifícia Universidade Católica de Campinas (PUC-Campinas), Campinas (SP), Brasil.

E-mail: paulo.oliveira@puc-campinas.edu.br

2Universidade Estadual de Campinas (UNICAMP), Campinas (SP), Brasil. E-mail: jmsilv52@gmail.com

${ }^{3}$ Universidade Estadual Paulista (UNESP), Tupã (SP), Brasil. E-mail: marcelo.marques.magalhaes@gmail.com

${ }^{4}$ Universidade Federal de Mato Grosso (UFMT), Cuiabá (MT), Brasil. E-mail: roneyfraga@gmail.com

How to cite: Oliveira, P. R. S., Silveira, J. M. F. J., Magalhães, M. M., \& Souza, R. F. (2020). International trade in GMOs: have markets paid premiums on Brazilian soybeans? Revista de Economia e Sociologia Rural, 58(1), e167573. https://doi.org/10.1590/1806-9479.2020.167573

\begin{abstract}
The introduction of GMO technology into global market chains and the rejection by consumers in some markets have led to the reorganization of soybean trades. Brazil has adopted the technology later than other countries and specialized in supplying non-GMO soybean between 1996 and 2005. On the other hand, the United States and Argentina, which adopted the technology in 1996, exported to countries with less social aversion to the GM-technology. The aim of this paper is to investigate the relation between changes in global market chains (price, source and destination and market shares) and GMO technology adoption, focusing on evidences for price premiums for non-GM soybeans produced in Brazil, by the analysis of the trade unit values (TUV). In order to do so, we employ multivariate methods (Principal Components and Hierarchical Cluster analyses) and estimate a Random Effect model based on a bilateral trade dataset covering the years from 1986 to 2010. Results show that GM-technology adoption significantly changed trade patterns. However, premiums were paid for Brazilian soybean only in niche markets, where the market share is lower.
\end{abstract}

Keywords: GM-food trade, market rejection, premium pricing, technology innovation and trade.

Resumo: A inserção dos Organismos Geneticamente Modificados (OGM) nas redes globais de comércio, em 1996, e a rejeição de demanda em alguns mercados importantes levaram à significativa reorganização do comércio mundial de soja. O Brasil adotou a tecnologia relativamente mais tarde, de forma que se especializou na oferta de soja convencional entre 1996 e 2005. Por outro lado, os Estados Unidos e a Argentina adotaram a tecnologia em 1996, e passaram a exportar, sobretudo, para destinos com menor aversão à tecnologia. O objetivo deste artigo é explorar as relações entre a adoção da tecnologia das sementes geneticamente modificadas e as mudanças nos mercados globais (preços, origens e destinos e parcelas de mercado), buscando, sobretudo, verificar a existência de preços diferenciados para a soja brasileira, a partir da análise dos valores unitários de comércio. Para tanto, foram utilizados métodos de análise multivariada (análise de componente principal e de agrupamento) e estimou-se um modelo de efeitos aleatórios a partir de uma base de dados de comércio de 1986 a 2010. Os resultados reforçam que a tecnologia altera o padrão de comércio, mas diferenciais de preço para a soja brasileira são verificados apenas em mercados de nicho, em que a parcela de mercado do Brasil é relativamente menor.

Palavras-chave: comércio de transgênicos, rejeição de mercado, diferencial de preços, inovação tecnológica e comércio. 


\section{Introduction}

The large and worldwide GMO technology adoption has been raising a range of concerns about global production and trade of grains. In some markets, restrictions to trade of GM-food raised up because people believe that GMOs are unhealthy and growing and distributing genetically modified (GM) crops are environmentally risky. On the other hand, many farmers believe that they may lower costs by growing GM crops. The aftermath of this trade-off between endogenous production reaps and exogenous demand rejection led to the emergence of a dual-market system supplying GMO and conventional grains to different consuming markets. This system generated extra-costs of Identity Preservation (IP) for every type of producer - GM or conventional - given the externality related to logistic and coexistence costs, since logistic system was designed to attain large economies of scale. As a result, strains and disputes - including disputes in multilateral bodies - came out from trade in GM-food. Besides final and intermediate consumer skepticism the absence of multilateral regulation able to unify approval and other regulatory issues led to commercial problems related to asynchronous and asymmetrical approval (Henseler et al., 2013; Faria \& Wieck, 2015).

In this context, soybeans case may be seen as representative of trade adjustments occurred in the period, due to its particular GM-technology adoption pace and the geographically concentrate ${ }^{1}$ supply structure in the international trade. In 2010, Brazil, Argentina and the United States accounted for over $87 \%$ of the worldwide exports of soybeans according to data from FAOSTAT (Food and Agriculture Organization of the United Nations, 2013). According to the same data, the US accounted on average for $56 \%$, Brazil for $24 \%$ and Argentina for $10 \%$ of world's soybeans exports from 1990 to 2010. United States and Argentina adopted GM-soybeans technology in 1996, the first year of commercial production. On the other hand, Brazil officially ${ }^{2}$ grew its first GM-soybeans crop solely in 2005. GM-soybean cultivation increased rapidly in these largest producing and exporting countries - estimates indicate that, in 2012, the share of GM-soybeans in total output was $93 \%$ in the US, whereas it was $100 \%$ in Argentina and 92\% in Brazil (James, 2013).

However, one can see a positive demand for non-GM soybeans, especially in European countries, which are highly dependent on soybean imports to supply the internal animal feedstock industry. Tillie \& Rodríguez-Cerezo (2015) estimated that the European demand is circa $8.3 \%$ for non-GM soybeans and $11.3 \%$ for non-GM soybean meal, which is accounts for 1.5 billion trades per year ${ }^{3}$.

This specific international supply and demand structure allows us to adequately assess the effects of GM-technology introduction in market shares and prices, since we can assume Brazil as a GMO-free country from 1996 to 2005, and a positive and significant demand for non-GM soybean at a global level.

The aim of this paper is to investigate the relation between changes in trade patterns (price, sourcing and destination and market shares) and GMO technology adoption, focusing on evidences for average price premiums for Brazilian soybeans based on trade unit values (TUV). In order to do so, we employ multivariate methods (Principal Components and Hierarchical Cluster analyses) and estimate a Random Effect model based on a dataset of bilateral trade comprising the period from 1986 to 2010. While we expect to find significant changes in trade patterns, we believe that Brazilian soybeans were exported at average global prices - measured via TUVs ${ }^{4}$ - in spite of being mostly recognized as non-GM soybeans. This is because of relatively large supply and low rate of identity preservation (IP) in Brazil. These hypotheses are supported by several studies on this case.

\footnotetext{
${ }^{1}$ We refer to the fact that Brazil, US and Argentina account for about $90 \%$ of the global soybean market.

${ }^{2}$ There is enough evidence to believe that Brazilians farmers grown GM crops before official approval for production in 2005.

${ }^{3}$ Tillie \& Rodríguez-Cerezo (2015) highlights some seasonal effects on price premiums, in a way that premiums increase considerably after September, when Brazilian stocks reach low levels. This volatility propelled a move toward new suppliers in India.

${ }^{4}$ See Berthou \& Emlinger (2011) for an introduction.
} 
More generally, studies in the field employed simulation and empirical modeling methods to investigate the effects of the dual-market systems emerging from the technology change and aversion.

Choi (2010), Lence \& Hayes (2001) and Desquilbet \& Bullock (2009) modeled markets for close substitutes under market clearing and rational agent assumptions. Choi (2010) and Lence \& Hayes (2001) used comparative statics while Desquilbet \& Bullock (2009) used simulations allowing multiple equilibriums.

Choi (2010) argues that a restrictive quota imposed by European markets on GMO-trade makes the price of GM food higher and decreases consumer surplus in Europe. Because of close substitutability, quota on GM product also makes the price of traditional food higher - via cross price elasticity of demand. Thus, the quota increases the producers' surpluses in producing country, increasing GM-food price, but does not increase the surpluses for traditional producers in Europe given the perfect competition in conventional crop markets.

Lence \& Hayes $(2001)^{5}$ found that premiums only exist when the GM output is relatively large when compared to non-GM output and demand for Non-GM grains are also relatively higher. When the conventional supply is relatively large, equilibrium conditions call for relative prices to be equal to 1. Premium prices arise as a required incentive to sustain conventional production under higher costs - i.e. IP and production costs - when there are consumers with strong preference for Non-GM grains and supply is relatively small. Moreover, IP costs may lead to part of non-GM product being commercialized without certification. Tillie \& Rodríguez-Cerezo (2015) also point to the opportunities costs of non-adoption for non-GM growers as a component of premium prices.

Desquilbet \& Bullock (2009) estimated a simulation model in which both types of grains are produced as well as a third good (alternative good). The model allowed for six equilibrium classes differing in which type of goods is produced and if premiums are positive or zero. They explicitly considered direct and indirect externality $\operatorname{costs}^{6}$ of transportation in the model as well as the endogenous production costs of each type of grain. Generally, producers take into account production costs, externality transportation costs, direct IP (identity preservation) costs, the technology fee and prices of GM and non-GM products to make their decisions on production levels. Net prices, instead, strongly depend on the level of hatred and IP costs, since it is the market price less total IP costs. If GM-technology is already being traded, the introduction of a small amount of "hatred" causes the IP demand curve to "appear" and the regular demand curve (i.e. the curve representing indifferent consumers) to shift-in. If there are no costs of IP, both IP and regular grain prices - i.e. non-segregated grains - remain equal to the regular price brought about the equilibrium with GMO technology and without hatred. Thus, given GMO technology exists, and there are no costs to identity preservation, the economy moves from a state with no hatred to a state with a small amount of hatred without affecting prices, producer welfare, or consumer welfare. The high IP costs, instead, allow multiple competitive equilibriums. Generally, the equilibrium depends on the size of the channels and premium prices may be positive or zero, depending on the total costs (IP + technology fee + endogenous costs) and the level of hatred. High level of hatred in comparison to total costs may lead to equilibrium with both regular producers - i.e. GM producers and Non-GM producers whose do not segregate grains - and IP producers and premiums. When externality costs are too high, only very high levels of hatred could allow a dual-market system, being equilibrium only possible with premium prices regime to pay off high IP and opportunity costs. Otherwise, too high opportunity costs for non-GM producers may lead dual-market to fade in spite of the level of hatred. Equilibria with zero price premiums - i.e. relative prices equal to 1 - may occur when seed market is a monopoly and

\footnotetext{
${ }^{5}$ They also assume that consumer preferences categorize consumers into broad homogenous groups, for example: feed industry is indifferent to GMO and non-GMO and the food industry prefers non-GMO grains.

${ }^{6}$ See Oliveira et al. (2012) for further information on segregation and logistic costs effects resulting from dual-market systems.
} 
IP costs are the same for IP producers and regular producers ${ }^{7}$ - given the significant output of IP grains.

In terms of empirical analyses, Foster (2010) points out that apart from consumer attitudes, the key driver of premiums is mandatory labeling of GM products in some key grain consuming countries (particularly high-income countries). The author examines whether premiums exist for some crops and countries, assuming European Union and Japan as main markets for certified non-GM soybeans, while Brazil, United States and Canada are the main suppliers. However, according to data presented by the author, Brazil certifies only a small amount of total conventional soybean internally produced - Brazil certified only $2.5 \%$ of all non-GMO grain domestically produced in 2008.

Based on data for premiums paid for Illinois growers, EU soybean meal import prices and Tokyo Grain Exchange (TGE) future markets, Foster (2010) argues that there is enough evidence to assume that premiums were paid for IP grains. Illinois growers would have traded their grains over and above normal cash prices at harvest time in autumn between 2004 and 2008. Moreover, the author argues, based on United Nations (UN) data, that imports price of Brazilian soymeal into the EU market had averaged 4 to 9 percent higher than soymeal imports from Argentina between 1996 and 2008. Considering that from February 2001 to August 2009 future prices for IP soybeans had exceeded 30\% of the GM-soybean, the author concludes that demand for IP product is increasing. On the other hand, supply of conventional grains is decreasing because of the opportunity costs related to non-adopting the technology, as also predicted by Desquilbet \& Bullock (2009), despite the fact that markets for IP crops are niche markets, reducing the scope of price premiums. Bullock \& Desquilbet (2002) performed analysis of TGE data that supports the information mentioned previously. According to the authors, conventional soybean prices per ton were USD 27.50 higher, on average, than GM-soybeans price between May 2000 and September 2001 - calculated as the difference between monthly prices of non-GM and GM-soybeans.

Also based on stock market data, Parcell \& Kalaitzandonakes (2004) studied shifts on prices by analyzing responses of Chicago Board of Trade (CBT) and TGE future prices of non-GMO soybeans to large food manufacturers and retailers' announcements of intentions to remove bioengineered ingredients from their branded products. Models (I, II and III) were estimated following a GARCH $(1,1)$ framework - which is more indicated for periods of varying volatility. In Models I and II the dependent variable is the percentage rate of return of CBOT futures price between open on day $t+1$ and settlement on day $t-1$. Model three has as dependent variable the percentage rate of return of TGE non-GMO soybean futures price between settlement on day $\mathrm{t}+1$ and settlement on day $\mathrm{t}-1$. Empirical results from "Model I" suggest that soybean futures prices did not respond to ban announcements. The joint F-test on the summation of the coefficients for the five days prior to and five days after the announcement is statistically significant; however, the summation of price changes around the announcement is not statistically significant. This further finding suggests that while there is some evidence of a soybean future price reaction, the market quickly filtered out the information. In Model II, when each announcement is analyzed separately, they found that there were no significant differences in the impact of individual bans and so no individual effects of firms can be seen. In Model III, estimation returned significant positive coefficients (at $p<0.01$ ) to TGE conventional rate of return and futures contracts rollover. Neither the firm ban announcement coefficient nor the summation of coefficients accounting for the rate of return the five days prior to and the five days after the announcement are statistically significant. This indicates that the impact of ban announcements by key food companies, as a proxy for the size of the non-bioengineered soybean market, was not considered large enough by the market to matter.

Last but not least, Tillie \& Rodríguez-Cerezo (2015), from a survey comprising several and diverse agents operating in soybean industry in Europe, provided an original and general

\footnotetext{
${ }^{7}$ Authors also discuss the different equilibrium when seed market is monopolist or competitive. Zero price premium equilibrium is possible only when seed industry is a monopoly and technology fee is set at profit-maximizing value. They found numerically that monopoly is maximized when it avoids equilibriums with premiums - when IP costs for regular producers are too high.
} 
overview of non-GM IP soybean market. According to the authors, premiums have been paid for non-GM IP soybeans, which were sold at prices $5 \%$ to $15 \%$ higher than GM soybeans between 2004 and 2012. After 2012, however, when Brazil has achieved significant rates of adoption, premiums were $20-30 \%$ higher in relation to GM soybeans. Authors explicitly related this change in the level of relative prices to imbalances between Brazilian supply and European demand for soybeans.

In sum, in spite of different approaches and assumptions several studies acknowledge that the dual-market system may affect prices in different ways depending mainly on the size of demand and IP costs. General equilibrium models predict equilibria with zero premium depending on IP costs, relative size of markets for IP grains, and concentration on seed industry. Empirical analyses based on stock market historical prices point to the existence of price premiums for IP grains, but to weak response of prices to announcements of bans by large corporations. The analysis we will carry out in this paper differs considerably in terms of methods and data. While the empirical literature presented above seeks to identify price premiums from historical price data from stock markets or micro-level premiums paid to relatively small fraction of producers, we investigate if late technology adoption in Brazil, which represented a period of large supply of non-GM soybeans in international markets, led to price premiums at the national level.

The paper is important from the policymaking perspective since it sheds light on the field of technology, regulation and their impacts on trade. Backward effects of technology adoption on trade are especially concerning to global market of agriculture commodities, since market regulation for these products will be always more susceptive to culturally-based judgments. National biotechnology regulations - and international disputes - were usually influenced by environmental, social, economic, ethical, ethnical, political and health-related issues.

This paper is organized in three sections other than this introduction. Section 2 introduces the methodology. Section 3 presents the analyses results. Finally, section 4 brings the final remarks.

\section{Methodology}

We carried out a two-step analysis. At first, two complementary multivariate exploratory methods were employed, namely the principal component analysis (PCA) and hierarchical cluster analysis (HCA). These methods prepared the dataset to test the hypotheses discussed above. In the following, a random effect model for panel data was performed looking to investigate how a set of variables - including those standing for average premiums - can explain the Brazilian share of global soybeans markets. Multivariate methods allow assessing changes in trade patterns related to the technology adoption, including price premiums and sourcing. Moreover, they also reveal how country-specific characteristics, such as income levels and dependence on soybean imports, can delineate regulatory frameworks and technology hatred. The Random Effect Model assess better how a set of observed variables explains the Brazilian market shares in selected international markets.

\subsection{Principal Components Analysis}

PCA is a multivariate method that can identify redundancy or correlation among a set of variables for the purpose of data reduction. In addition, it can explain the structure of variance and covariance of a vector of random variables. The method is for exploratory analyses since neither normality nor preceding causal relationship among variables are required. However, when principal components are normally distributed, the ellipsoids of confidence can be used for hypothesis tests.

Principal components are orthogonal variables obtained by descending order of variance, from the initial variables at different levels of correlation (Johnson \& Wichern, 2002; Goodall \& Jolliffe, 1988; Everitt \& Hothorn, 2011). Let $\mathbf{S}$ be a matrix of variance and covariance of a set of variables $Y_{1}, Y_{2}, \cdots, Y_{p}$, paired to eigenvalues-eigenvectors $\left(\lambda_{j}, \mathbf{e}_{j}\right), j=1,2, \ldots, p$, the $j^{\text {th }}$ principal component is given by 
$C_{j}=e_{1 j} Y_{l}+e_{2 j} Y_{2}+\cdots+e_{p j} Y_{p}=\mathbf{Y} \mathbf{e}_{j}$

In which $\lambda_{1} \geq \lambda_{2} \geq \cdots \geq \lambda_{p} \geq 0 ; \mathrm{Y}$ is the matrix of original data of variables $Y_{1}, Y_{2}, \cdots, Y_{p} ; \mathbf{e}_{j}^{\prime} \mathbf{e}_{j}=\sum_{j=l}^{p} \mathbf{e}_{j}^{2}=1$; $\mathbf{e}^{\prime}{ }_{j} \mathbf{e}_{j^{\prime}}=0$, for $j \neq j^{\prime}$ and $j, j^{\prime}=1,2, \ldots, p$.

The properties of the principal components after spectral decomposition are: (i) $\operatorname{var}\left(C_{j}\right)=\operatorname{var}\left(\mathbf{Y e}_{j}\right)=\lambda_{j}$ and (ii) $\operatorname{cov}\left(C_{j} ; C_{j^{\prime}}\right)=\operatorname{cov}\left(\mathbf{Y e}_{j} ; \mathbf{Y e} \mathbf{j}_{j^{\prime}}\right)=0$, which means that $C_{j}$ and $C_{j^{\prime}}$ are orthogonal when $j, j^{\prime}=1,2, \ldots, p$.

In PCA the new components $C_{j}$ are sensitive to the scaling of variables. A solution could be to scale the variables, centering the mean to zero $Z_{j}=\left(Y_{j}-\bar{y}_{j}\right) / \sqrt{\sigma_{j j}}$. In the same way, the correlation matrix $\mathbf{R}$ may be used to estimate the sum of the eigenvalues that equals the number of variables:

$$
\sum_{j=1}^{p} \lambda_{j}=\operatorname{tr}(\mathbf{R})=p
$$

The share of each component $C_{j}$ is given by $\lambda_{j} / p, j=1,2, \ldots, p$. The correlation between the component $C_{j}$ and the scaled variable $Z_{j}$ is given by

$$
\rho_{\left[C_{j}, Z_{j^{\prime}}\right]}=\frac{\operatorname{cov}\left(C_{j} ; Z_{j^{\prime}}\right)}{\sqrt{\operatorname{var}\left(C_{j}\right) \operatorname{var}\left(Z_{j^{\prime}}\right)}}=\frac{\lambda_{j} e_{j j^{\prime}}}{\sqrt{\lambda_{j}} \sqrt{e_{j j^{\prime}}}}=e_{j j^{\prime}} \sqrt{\lambda_{j}}
$$

One of the goals of PCA is to compress data of $p$ variables into a minimum of $k$ orthogonal components $(k<p)$, preserving as much as possible the original variance, thus, maintaining the level of information. Combinations of overlapping criteria were used to define the number of principal components. They may be summarized as follows: (i) selection of the first components until the curve of the scree-plot graphic bent parallel to the horizontal axis; (ii) selection of the components with eigenvalues higher than 1 or higher than 0.7 and; (iii) selection of the components until the accumulated share reach $70 \%$ of the total variance, which corresponds to the first criteria (Cattell, 1966; Kaiser, 1960; Jolliffe, 1972). After the selection of the components, a rotation method (e. g. varimax, promax etc.) may be performed to improve the level of variance explanation for the selected components.

The last step of PCA is the estimation of the factor scores for each observation of the dataset. These scores will be used later in the hierarchical cluster analysis.

The interpretation of the principal components is based on the most important variables. One should keep variables $Y_{j}$ with linear correlation coefficients (or loadings) to the components $C_{j}$ higher than $|0.50|$. On the other hand, variables highly correlated with principal components that presented low variance must be discarded.

The software R and packages psych and FactoMineR were used for PCA (Revelle, 2013; Lê et al., 2008).

\subsection{Hierarchical Cluster Analysis}

The Hierarchical Cluster Analysis (HCA) is a technique of classification of individuals or objects into homogeneous groups. The agglomerative clustering begins with the individuals producing a series of partitions of data, from the single element $n$ to a unique group for the whole dataset 1, $P_{n}, P_{n-1}, \cdots, P_{1}$. The common steps are: (i) Begin with every individual as a cluster $C_{1}, C_{2}, \cdots, C_{n}$; (ii) find the nearest pair of distinct clusters $C_{i}$ and $C_{j}$, merge both, delete the second $C_{j}$, and decrease the number of clusters; (iii) if the number of clusters equals one, then stop; otherwise return to 1 (Everitt \& Hothorn, 2011). Looking for the nearest pair requires a measure of distance inter-individuals, given by a distance matrix or similarity matrix $D_{(n x n)}$, which is symmetric and has zeros in the diagonal. We used the Euclidean distance given by 
$d_{i j}=\sqrt{\sum_{k=1}^{p}\left(y_{i k}-y_{j k}\right)^{2}}$

where $d_{i j}$ is the distance between elements $i$ and $j$, with $i, j=1,2, \ldots, n ; y_{i k}$ and $y_{j k}$ are the observed characteristics $k=1,2, \ldots, p$, of the elements $i$ and $j$. We scaled and centered the data before the distance calculation.

We used the method of Ward for the agglomerative clustering, which is based on the minimizing of internal homogeneity of sum of squared errors (SSE):

$\operatorname{SSE}=\sum_{i=1}^{n}\left(\mathbf{y}_{i}-\overline{\mathbf{y}}\right)^{\prime}\left(\mathbf{y}_{i}-\overline{\mathbf{y}}\right)$

in which $\mathbf{y}_{i}$ is the multivariate vector of measures of the individual $i$ and; $\overline{\mathbf{y}}$ is the mean of the whole dataset (Ward Junior, 1963).

There are many methods to select the best number of clusters, but all of them depend on the researcher knowledge about the variables. The hierarchical classification tree, or dendrogram, plots the vertical distances of clusters dissimilarities and the cluster grouping. One should choose a height for the partitioning, looking for a distance between two levels of aggregation as large as possible, avoiding few groups on the one hand and too many on the other.

The software R and packages cluster and stats were used for HCA (R Core Team, 2012; Maechler et al., 2012).

\subsection{Random Effect Model}

Finally, we employed an econometric model for panel data. Based on Wooldridge (2010), we decide on random effects instead fixed effects after performing Hausman test. The reasoning behind random effects model is that, unlike the fixed effects model, the variation across entities is assumed to be random and uncorrelated with the predictor or independent variables included in the model. In other words, random effects model assumes that entity effects are randomly distributed around a constant mean $\beta_{0}$. Random effects model has the advantage of including time invariant variables, which would be absorbed by the intercept in the fixed effects model.

In terms of model specification, we followed a progressive based on findings of (Oliveira et al., 2012) and other papers cited above. The first specification is related to the hypothesis that the share of soybean imports from Brazil (sbr3) increased for countries averse to GMO technology (aver), and in markets with more years of mandatory labeling (labt):

$\operatorname{sbr} 3_{i t}=\beta_{0}+\beta_{1}$ aver $_{i t}+\beta_{2} l a b t_{i t}+v_{i t}$

In the following, taking into consideration that Brazilian soy was preferred in markets with high levels of hatred and/or longer time of mandatory labeling; we assumed that relative prices should respond to differentiation in international markets. In other words, we expected that the ratio between Brazilian soy_prices and average prices for each year $(r m b r)$ should be different - intuitively higher - in markets with larger Brazilian shares $(s b r 3)^{8}$ :

$$
s b r 3_{i t}=\beta_{0}+\beta_{1} a v e r_{i t}+\beta_{2} l a b t_{i t}+\beta_{3} r m b r_{i t}+v_{i t}
$$

In the third specification, we added variables to control for the destination effect. The importance of destination was considered according to their volume of agricultural

${ }^{8}$ Multivariate methods pointed out to a seemly counterintuitive result: prices are reduced for Brazilian soybean in those markets where the country has larger shares. This result was confirmed by the econometric model. 
products imports (stimp) and share of soybean imports on total agricultural imports (ssoy) and income level of destination was measured by per capita purchasing power parity (spppc). Based on literature, we can assume that high-income countries are more averse to technology and so they import proportionally more from Brazil. On the other hand, countries with increasing imports of agricultural goods - including soybeans - are mostly developing countries with less aversion to technology, and thus importing proportionally less from Brazil - since they import high volumes from anywhere. We used scaled values for both variables to avoid scale effects on the estimated parameters:

$s b r 3_{i t}=\beta_{0}+\beta_{1}$ aver $_{i t}+\beta_{2}$ labt $_{i t}+\beta_{3} r m b r_{i t}+\beta_{4}$ spppc $_{i t}+\beta_{5}$ stimp $_{i t}+\beta_{6}$ ssoy $_{i t}+v_{i t}$

The variables selection process also considered results from the multivariate methods. Estimations were performed in Stata, making use of panel data commands including option for robust variance estimates to treat heteroskedasticity.

\subsection{Dataset}

The dataset was built mainly based on data collected from Faostat trade matrices, and complemented by data from the USDA reports and World Bank. We started with 18,766 records for international soybean trade, 25 years of observations, 6 original variables, 148 importing countries and 3 exporting countries - Argentina, Brazil and United States. We eliminated double records and filtered non-consistent values and single outliers. The exporting countries were filtered on the side of importing countries to avoid recursive sum. Moreover, imports from China were filtered because it was markedly misleading the results. The final dataset records consist of annual in-flows of soybeans by source - Argentina, Brazil and USA - from 1986 to 2010.

A new set of variables was built based on final dataset: Scaled value of Total Agriculture Imports (USD 1000) (stimp); Logarithm of Argentina soybean exports (ton) (Iqar); Logarithm of USA soybean exports (ton) (Iqus); Share of soybean imports of total agricultural imports in the destination country (ssoy); Share of soybean imports from Brazil over the total from Argentina, Brazil and USA (sbr3); Ratio of premium pricing from Brazil in relation to Argentina (rarg); Ratio of premium pricing from Brazil in relation to USA (rusa); Ratio of Brazilian premium pricing in relation to the annual average price in other markets $(r m b r)$; and, Annual growth rate of agricultural imports (\%) (grag).

Information on adoption of mandatory labeling and most restrictive regulations including bans to GMO was gathered from the USDA gains reports. From this, we created the variables Time of GMO labeling (years) (labt); and Aversion to GMO (binary) (aver) ${ }^{9}$.

Information on Gross Domestic Product (GDP, PPP total and per capita current international USD) is from the World Bank Databases. Data were transformed into the logarithm of GDP based on purchasing-power-parity per capita GDP (USD/year) (Ippc) and Scaled GDP based on purchasing-power-parity per capita GDP (USD/year) (spppc).

We transformed some of the variables into logarithm because they have very strong skewness (Iqar, Iqus, Ippc). Some of the variables received ratio transformation instead of simple difference, which produced more variance for the principal components and cluster hierarchical analysis ( $r a r g, r u s a, r m b r)$. The annual growth rate of agriculture imports was segmented according to the period of analysis.

Except for scaled value of total imports (stimp) and scaled GDP based on purchasingpower-parity $(s p p p c)$, all the variables above were used in the exploratory analysis and missing values were removed.

Finally, as multivariate methods will be applied to discrete periods, the final datasets comprised 60 observations in the period 1986-1993, 126 observations in the period 1996-2004, and 101 observations in the period 2005-2010. Each pair of country and year was considered

${ }^{9}$ Aversion (aver) is a dummy variable to discriminate countries most commonly regard as averse to the GM-technology. These countries are: France, Germany, Ireland, Japan, The Netherlands, Norway, Sweden and Switzerland. 
an "entity" for the multivariate analysis. It makes sense, since countries have changed their positions toward technologies across the years.

The random effects model was performed on data from 1996-2010, resulting in an unbalanced panel of 479 observations for 69 importing countries.

\section{Results}

\subsection{Multivariate methods}

Results from multivariate methods, PCA and HCA, are presented for 3 periods of analysis. Period I (1986-1993) is marked by the absence of GM-production worldwide. Results from this period when compared to period with GM-production Period II (1996-2005) allow us to better assess the market adjustments related to GM-technology adoption by the US and Argentina. Finally, Period III (2005-2010) reveals that some changes occurred in Period II remains, in spite of Brazilian rapid technology adoption. Factors and variables loadings for the analysis carried over the three periods are summarized in Tables 1 and 2 . Variables vectors and observations clusters are presented in the Figures 1 and 2.

Table 1. Eigenvalues, percentage of variance and cumulative percentage of variance of principal component analysis, periods: 1986-1993, 1996-2004, and 2005-2010

\begin{tabular}{|c|c|c|c|c|c|c|c|c|c|}
\hline \multirow[b]{3}{*}{ PC } & \multicolumn{9}{|c|}{ Period } \\
\hline & \multicolumn{3}{|c|}{ 1986-1993 } & \multicolumn{3}{|c|}{$1996-2004$} & \multicolumn{3}{|c|}{ 2005-2010 } \\
\hline & $\begin{array}{l}\text { Eigen } \\
\text { value }\end{array}$ & $\begin{array}{c}\text { Variance } \\
(\%)\end{array}$ & $\begin{array}{c}\text { Cumulative } \\
\text { Variance } \\
(\%)\end{array}$ & $\begin{array}{l}\text { Eigen } \\
\text { value }\end{array}$ & $\begin{array}{c}\text { Variance } \\
(\%)\end{array}$ & $\begin{array}{c}\text { Cumulative } \\
\text { Variance } \\
(\%)\end{array}$ & $\begin{array}{l}\text { Eigen } \\
\text { value }\end{array}$ & $\begin{array}{c}\text { Variance } \\
(\%)\end{array}$ & $\begin{array}{c}\text { Cumulative } \\
\text { Variance } \\
(\%)\end{array}$ \\
\hline 1 & 2.32 & 25.77 & 25.77 & 3.32 & 33.21 & 33.21 & 3.74 & 34.04 & 34.04 \\
\hline 2 & 1.82 & 20.19 & 45.95 & 2.30 & 23.01 & 56.21 & 2.29 & 20.80 & 54.84 \\
\hline 3 & 1.52 & 16.89 & 62.84 & 1.13 & 11.30 & 67.52 & 1.46 & 13.31 & 68.15 \\
\hline 4 & 1.11 & 12.38 & 75.22 & 0.97 & 9.65 & 77.17 & 0.99 & 8.99 & 77.14 \\
\hline 5 & 0.79 & 8.78 & 84.00 & 0.82 & 8.23 & 85.40 & 0.69 & 6.26 & 83.40 \\
\hline 6 & 0.53 & 5.88 & 89.89 & 0.49 & 4.94 & 90.34 & 0.54 & 4.92 & 88.32 \\
\hline 7 & 0.46 & 5.09 & 94.98 & 0.35 & 3.49 & 93.83 & 0.43 & 3.90 & 92.22 \\
\hline 8 & 0.30 & 3.28 & 98.27 & 0.26 & 2.65 & 96.48 & 0.35 & 3.14 & 95.35 \\
\hline 9 & 0.16 & 1.73 & 100.00 & 0.23 & 2.26 & 98.74 & 0.21 & 1.91 & 97.27 \\
\hline 10 & - & - & - & 0.13 & 1.26 & 100.00 & 0.15 & 1.38 & 98.65 \\
\hline 11 & - & - & - & - & - & - & 0.15 & 1.35 & 100.00 \\
\hline
\end{tabular}

Source: Elaborated by the authors based on data from Faostat, USDA reports and World Bank.

Table 2. Coordinates and cosine-squared of principal component analysis, periods: 1986-1993, 19962004, and 2005-2010

\begin{tabular}{|c|c|c|c|c|c|c|c|c|c|}
\hline \multirow{3}{*}{ Variable } & \multicolumn{9}{|c|}{ Principal Components (1-3) } \\
\hline & \multicolumn{3}{|c|}{$1986-1993$} & \multicolumn{3}{|c|}{$1996-2004$} & \multicolumn{3}{|c|}{ 2005-2010 } \\
\hline & PC1 & PC2 & PC3 & PC1 & PC2 & PC3 & PC1 & PC2 & PC3 \\
\hline Imports from Argentina & 0.00 & 0.28 & 0.74 & -0.70 & 0.06 & 0.44 & 0.56 & -0.53 & -0.03 \\
\hline Imports from USA & 0.12 & 0.36 & 0.50 & -0.52 & -0.57 & 0.35 & 0.25 & -0.09 & 0.89 \\
\hline $\begin{array}{l}\text { Share of soybeans/ } \\
\text { agriculture imports }\end{array}$ & 0.73 & 0.03 & 0.26 & -0.65 & -0.14 & 0.53 & 0.50 & -0.57 & 0.22 \\
\hline $\begin{array}{l}\text { Share of Brazilian soybeans } \\
\text { imports }\end{array}$ & -0.56 & 0.26 & -0.26 & 0.63 & -0.43 & 0.28 & -0.68 & -0.37 & -0.31 \\
\hline Premium Brazil/ Argentina & 0.24 & 0.55 & 0.33 & -0.06 & 0.80 & 0.34 & 0.64 & 0.35 & -0.14 \\
\hline Premium Brazil/ USA & 0.28 & 0.79 & -0.28 & 0.38 & 0.48 & 0.32 & 0.26 & 0.75 & 0.35 \\
\hline
\end{tabular}




\begin{tabular}{|c|c|c|c|c|c|c|c|c|c|}
\hline \multirow{3}{*}{ Variable } & \multicolumn{9}{|c|}{ Principal Components (1-3) } \\
\hline & \multicolumn{3}{|c|}{ 1986-1993 } & \multicolumn{3}{|c|}{$1996-2004$} & \multicolumn{3}{|c|}{ 2005-2010 } \\
\hline & PC1 & PC2 & PC3 & PC1 & PC2 & PC3 & PC1 & PC2 & PC3 \\
\hline $\begin{array}{l}\text { Premium Brazil/ annual } \\
\text { mean }\end{array}$ & 0.03 & 0.73 & -0.53 & 0.43 & 0.81 & 0.18 & 0.24 & 0.84 & -0.23 \\
\hline $\begin{array}{l}\text { Purchasing-power-parity } \\
\text { per capita }\end{array}$ & -0.76 & 0.23 & 0.33 & 0.71 & -0.41 & 0.29 & -0.76 & 0.22 & 0.07 \\
\hline $\begin{array}{l}\text { Growth rate of annual agr. } \\
\text { imports }\end{array}$ & 0.85 & -0.14 & -0.15 & - & - & - & 0.76 & -0.23 & -0.01 \\
\hline GMO labeling time & - & - & - & 0.80 & -0.20 & 0.12 & -0.82 & -0.17 & 0.15 \\
\hline Aversion to GMO & - & - & - & 0.53 & -0.19 & 0.32 & -0.54 & 0.10 & 0.54 \\
\hline
\end{tabular}

Source: Elaborated by the authors based on data from Faostat, USDA reports and World Bank.

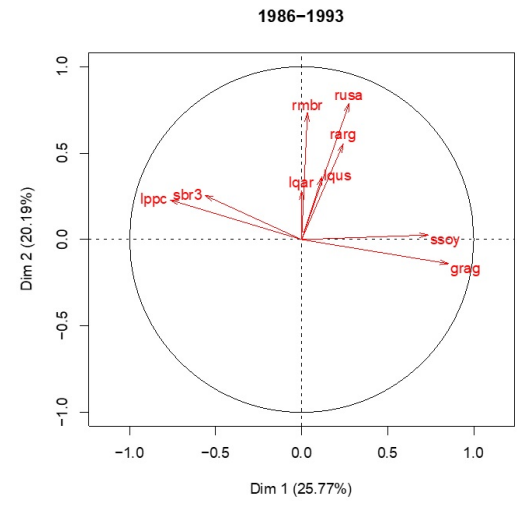

(a)

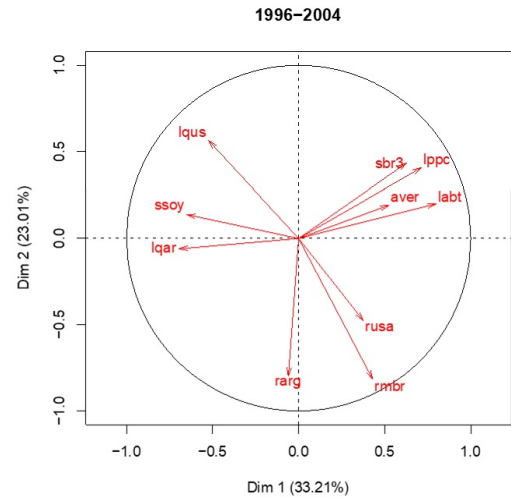

(b)

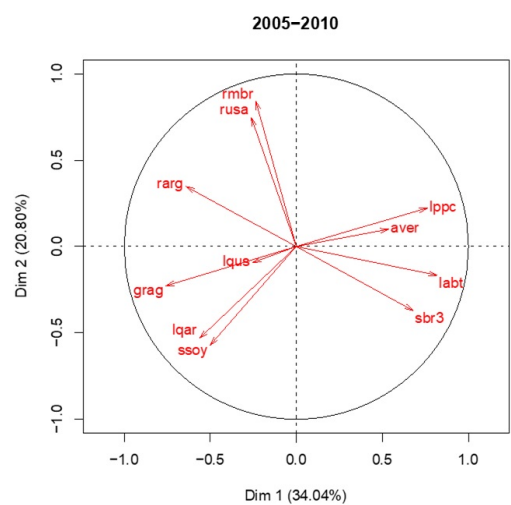

(c)

Figure 1. Variables vectors, periods: (a) 1986-1993, (b) 1996-2004, (c) 2005-2010. Source: Elaborated by the authors based on data from Faostat, USDA reports and World Bank. 


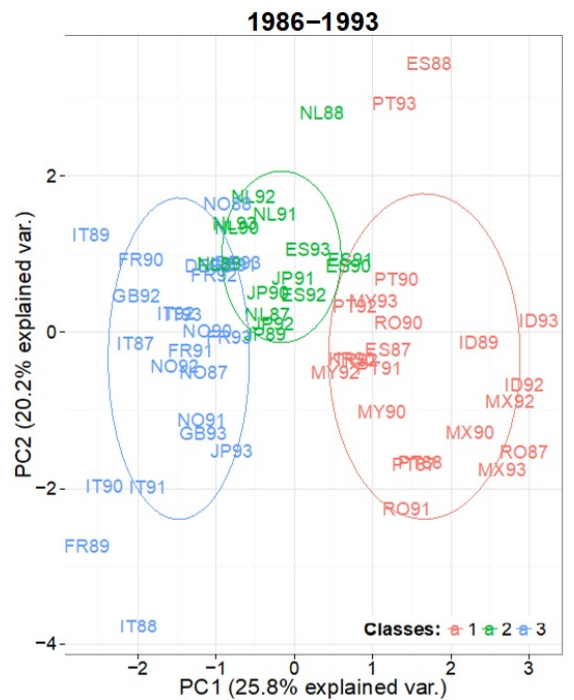

(a)

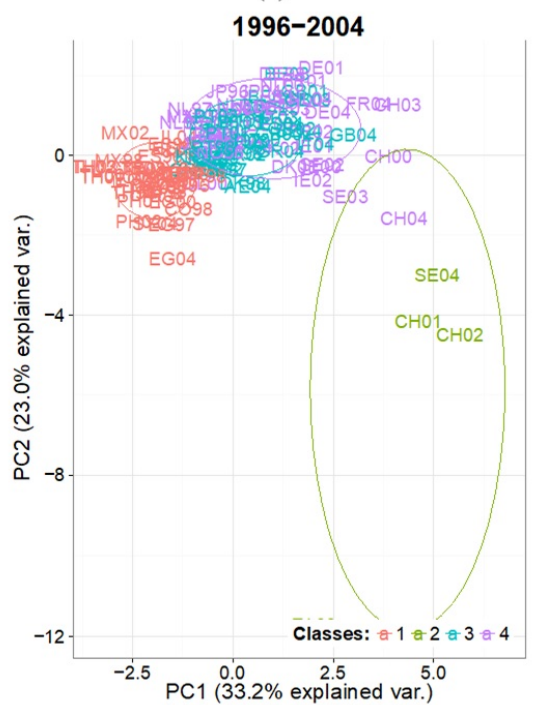

(b)

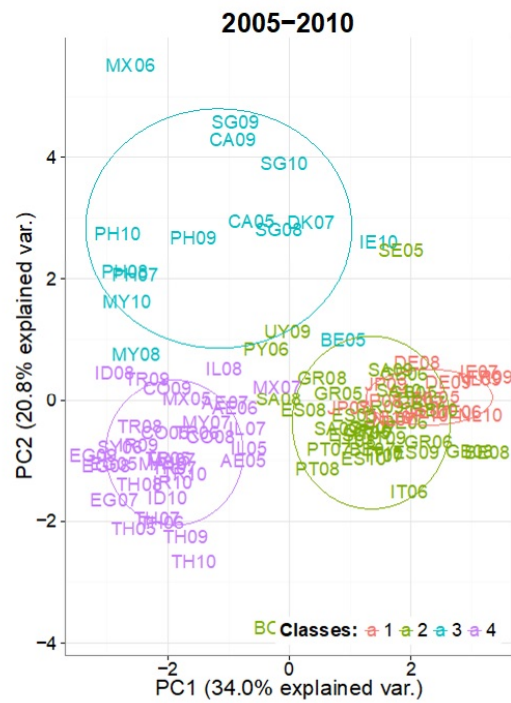

(c)

Figure 2. Observations classified by clusters, periods: (a) 1986-1993, (b) 1996-2004, (c) 2005-2010. Source: Elaborated by the authors based on data from Faostat, USDA reports and World Bank. 


\section{Period I (1986-1993)}

Considering the importance of this period to make comparisons with subsequent periods, we decided to advance with PCA in spite of the fact that KMO test indicated some level of sample inadequacy (level of adequacy 0.44). On the other hand, Bartlett's test estimated a p-value $<0.01$. Sample is made up of 60 entities and 9 variables. Factors 1,2 and 3 were taken into consideration and they account for $62.84 \%$ of accumulated variance (Table 1 ).

Factor 1 returned high positive loadings on variables standing for the relative importance of soybean for total agricultural imports (ssoy) and the growth rate of agricultural imports (grag) (Table 2). Broadly, these variables measured how important the soybeans are for a specific market and how this market is increasing its agricultural intakes. Assuming that, this factor may be renamed as "Booming Markets I". High per capita income has negative and high loadings on "Booming Markets I" factor, meaning that the "Booming Markets I" are low-income markets. Moreover, note that Brazilian share of the soybean market is also negatively correlated with "Booming Markets I". Factor 2 (Period I), instead, is marked by high loadings on variables that stand for situations in which Brazil managed to trade with premiums. Thus, let factor 2 be renamed as "Brazil's Price Premiums I". Note that premiums are orthogonal to other variables, i.e., there is no correlation between premiums and other variables during this period (Figure 1a). Taking into consideration that only conventional soybeans were traded, the assumption of non-differentiation between export countries is reasonable. Finally, factor 3 can be defined as "US and AR exports I", based on the weight exports from these countries have on it.

From the hierarchical cluster analysis, we can see that consuming markets could be divided into fewer large groups because of soybean could only be slightly differentiated according to exporting source. Cutting the dendrogram at a height of 15 we obtained 3 different groups. Variables with $p$-value $<0.01$ were selected as key variables within groups. The entities clustered into each group can be seen in Table 3, and Figure 2a. Group 1 is best described by the high growth rate of agricultural imports, high relative importance of soybeans and low-income countries. Thus, this group is close to what we previously named as "Booming Markets I". Developing economies in Asia and Latin America and low-income countries in Europe came together into this group. Group 2, instead, is well-marked by larger US soybeans imports. As a result, group 2 will be named as "Friends of US I". Spain, in the early 1990 's, and The Netherlands ${ }^{10}$ and Japan during the whole period may be taken as representatives of this group during Period I. At last, high-income countries and mature markets are in group 3, henceforth "High-Income-markets I". It is worth noting that "High-income markets I" shows the other side of the coin when compared to "Booming Markets I". High-income economies in Europe came together in this group, and they were already chiefly importing soybeans from Brazil. Along with the relatively low market shares of Brazil in "Booming Markets I", it indicates that Brazil sets out a move toward a specialization in supplying high-income markets before the commercial release of GM-crops.

Table 3. Descriptive statistics of classes of soybean trade entities (country/year), Period I (1986-1993)

\begin{tabular}{|c|c|c|c|c|c|c|}
\hline \multirow[b]{2}{*}{ Cluster } & \multirow{2}{*}{$\begin{array}{l}\text { Observations } \\
\text { Countries \& Years }\end{array}$} & \multirow{2}{*}{$\begin{array}{l}\text { Cluster } \\
\text { Name }\end{array}$} & \multicolumn{4}{|c|}{ Descriptive Statistics } \\
\hline & & & Variable & Mean & $\begin{array}{l}\text { Standard } \\
\text { Deviation }\end{array}$ & $\begin{array}{c}\text { test } \\
\text { Value }^{(1)}\end{array}$ \\
\hline \multirow{3}{*}{$\begin{array}{c}1 \\
(n=22)\end{array}$} & $\begin{array}{l}\text { Indonesia } \\
(89,92,93)\end{array}$ & \multirow{3}{*}{$\begin{array}{l}\text { Booming } \\
\text { Markets I }\end{array}$} & $\begin{array}{c}\text { Imports from } \\
\text { Argentina LN(ton) }\end{array}$ & 10.91 & 1.10 & - \\
\hline & $\begin{array}{l}\text { Malaysia } \\
(90,92,93)\end{array}$ & & $\begin{array}{c}\text { Imports from USA } \\
\text { LN(ton) }\end{array}$ & 12.83 & 1.03 & $\begin{array}{l}- \\
1.29\end{array}$ \\
\hline & $\begin{array}{c}\text { Mexico } \\
(90,92,93)\end{array}$ & & $\begin{array}{c}\text { Share of soybean/ agr. } \\
\text { imports }\end{array}$ & 0.08 & 0.04 & 2.70 \\
\hline
\end{tabular}

\footnotetext{
${ }^{10}$ It is important to highlight that Rotterdam is an entry port to large amounts of soybean to be distributed to the whole Europe.
} 
Table 3. Continued...

\begin{tabular}{|c|c|c|c|c|c|c|c|}
\hline \multirow[b]{2}{*}{ Cluster } & \multirow{2}{*}{$\begin{array}{l}\text { Observations } \\
\text { Countries \& Years }\end{array}$} & \multirow{2}{*}{$\begin{array}{l}\text { Cluster } \\
\text { Name }\end{array}$} & \multicolumn{5}{|c|}{ Descriptive Statistics } \\
\hline & & & \multirow{2}{*}{$\begin{array}{c}\text { Variable } \\
\text { Share of Brazilian } \\
\text { soybean imports }\end{array}$} & \multirow{2}{*}{$\begin{array}{l}\text { Mean } \\
0.11\end{array}$} & \multirow{2}{*}{$\begin{array}{c}\begin{array}{c}\text { Standard } \\
\text { Deviation }\end{array} \\
0.09\end{array}$} & \multicolumn{2}{|c|}{$\begin{array}{c}\text { test } \\
\text { Value }\end{array}$} \\
\hline & \multirow{8}{*}{$\begin{array}{c}\text { Portugal }(87,88, \\
90,91,92,93) \\
\text { Romania }(87,90,91) \\
\text { South Korea }(90) \\
\text { Spain }(87,88) \\
\text { Turkey }(92)\end{array}$} & & & & & $\begin{array}{c}- \\
2.36\end{array}$ & * \\
\hline & & & $\begin{array}{l}\text { Premium Brazil/ } \\
\text { Argentina (ratio) }\end{array}$ & 1.05 & 0.12 & 0.90 & \\
\hline & & & $\begin{array}{c}\text { Premium Brazil/ USA } \\
\text { (ratio) }\end{array}$ & 0.98 & 0.06 & 0.74 & \\
\hline & & & $\begin{array}{l}\text { Premium Brazil/ } \\
\text { mean (ratio) }\end{array}$ & 1.00 & 0.05 & $\begin{array}{c}- \\
0.09\end{array}$ & \\
\hline & & & $\begin{array}{l}\text { PPP per capita } \\
\text { LN(USD/year) }\end{array}$ & 8.78 & 0.63 & $\begin{array}{c}- \\
4.16\end{array}$ & $* * *$ \\
\hline & & & $\begin{array}{l}\text { Growth rate of agr. } \\
\text { imports (\%) }\end{array}$ & 13.58 & 3.79 & 4.34 & $\star \star \star$ \\
\hline & & & $\begin{array}{c}\text { GMO labeling time } \\
\text { (years) }\end{array}$ & & & & \\
\hline & & & $\begin{array}{l}\text { Aversion to GMO } \\
(\text { dummy })\end{array}$ & & & & \\
\hline \multirow{11}{*}{$\begin{array}{c}2 \\
(n=15)\end{array}$} & \multirow{11}{*}{$\begin{array}{c}\text { Japan } \\
(89,90,91,92) \\
\text { Spain } \\
(90,91,92,93) \\
\text { The Netherlands } \\
(87,88,89,90,91 \\
92,93)\end{array}$} & \multirow{11}{*}{$\begin{array}{l}\text { Friends } \\
\text { of US I }\end{array}$} & $\begin{array}{c}\text { Imports from } \\
\text { Argentina LN(ton) }\end{array}$ & 12.35 & 1.69 & 2.24 & * \\
\hline & & & $\begin{array}{c}\text { Imports from USA } \\
\text { LN(ton) }\end{array}$ & 14.73 & 0.44 & 4.75 & $\star * *$ \\
\hline & & & $\begin{array}{l}\text { Share of soybean/ } \\
\text { agr. imports }\end{array}$ & 0.06 & 0.02 & 1.12 & \\
\hline & & & $\begin{array}{l}\text { Share of Brazilian } \\
\text { soybean imports }\end{array}$ & 0.21 & 0.09 & 0.98 & \\
\hline & & & $\begin{array}{l}\text { Premium Brazil/ } \\
\text { Argentina (ratio) }\end{array}$ & 1.03 & 0.05 & 0.32 & \\
\hline & & & $\begin{array}{c}\text { Premium Brazil/ USA } \\
\text { (ratio) }\end{array}$ & 0.99 & 0.04 & 1.22 & \\
\hline & & & $\begin{array}{c}\text { Premium Brazil/ } \\
\text { mean (ratio) }\end{array}$ & 1.00 & 0.01 & 0.70 & \\
\hline & & & $\begin{array}{l}\text { PPP per capita } \\
\text { LN(USD/year) }\end{array}$ & 9.78 & 0.14 & 2.04 & * \\
\hline & & & $\begin{array}{l}\text { Growth rate of agr. } \\
\text { imports (\%) }\end{array}$ & 7.35 & 3.17 & $\begin{array}{c}- \\
0.78\end{array}$ & \\
\hline & & & $\begin{array}{c}\text { GMO labeling time } \\
\text { (years) }\end{array}$ & & & & \\
\hline & & & $\begin{array}{l}\text { Aversion to GMO } \\
\text { (dummy) }\end{array}$ & & & & \\
\hline \multirow{5}{*}{$\begin{array}{c}3 \\
(n=23)\end{array}$} & \multirow{5}{*}{$\begin{array}{c}\text { France } \\
(89,90,91,92,93) \\
\text { Germany }(92,93) \\
\text { Great Britain } \\
(91,92,93) \\
\text { Italy }(87,88,89,90, \\
91,92,93) \\
\text { Japan }(93) \\
\text { Norway } \\
(87,88,90,91,92)\end{array}$} & \multirow{5}{*}{$\begin{array}{c}\text { High- } \\
\text { income } \\
\text { markets I }\end{array}$} & $\begin{array}{c}\text { Imports from } \\
\text { Argentina LN(ton) }\end{array}$ & 10.76 & 2.07 & $\begin{array}{c}- \\
1.00\end{array}$ & \\
\hline & & & $\begin{array}{c}\text { Imports from USA } \\
\text { LN(ton) }\end{array}$ & 12.57 & 0.84 & 2.28 & * \\
\hline & & & $\begin{array}{c}\text { Share of soybean/ agr. } \\
\text { imports }\end{array}$ & 0.02 & 0.02 & 3.90 & $\star \star \star$ \\
\hline & & & $\begin{array}{l}\text { Share of Brazilian } \\
\text { soybean imports }\end{array}$ & 0.22 & 0.16 & 1.34 & \\
\hline & & & $\begin{array}{l}\text { Premium Brazil/ } \\
\text { Argentina (ratio) }\end{array}$ & 0.99 & 0.15 & $\begin{array}{c}- \\
1.02\end{array}$ & \\
\hline
\end{tabular}


Table 3. Continued...

\begin{tabular}{|c|c|c|c|c|c|c|}
\hline \multirow[b]{2}{*}{ Cluster } & \multirow{2}{*}{$\begin{array}{c}\text { Observations } \\
\text { Countries \& Years }\end{array}$} & \multirow{2}{*}{$\begin{array}{l}\text { Cluster } \\
\text { Name }\end{array}$} & \multicolumn{4}{|c|}{ Descriptive Statistics } \\
\hline & & & Variable & Mean & $\begin{array}{l}\text { Standard } \\
\text { Deviation }\end{array}$ & $\begin{array}{c}\text { test } \\
\text { Value }^{(1)}\end{array}$ \\
\hline & & & $\begin{array}{c}\text { Premium Brazil/ USA } \\
\text { (ratio) }\end{array}$ & 0.94 & 0.09 & 1.46 \\
\hline & & & $\begin{array}{l}\text { Premium Brazil/ } \\
\text { mean (ratio) }\end{array}$ & 0.99 & 0.04 & 0.39 \\
\hline & & & $\begin{array}{l}\text { PPP per capita } \\
\text { LN(USD/year) }\end{array}$ & 9.85 & 0.15 & 3.02 \\
\hline & & & $\begin{array}{l}\text { Growth rate of agr. } \\
\text { imports (\%) }\end{array}$ & 4.20 & 1.69 & $-\overline{1} \quad * * \star$ \\
\hline & & & $\begin{array}{l}\text { GMO labeling time } \\
\text { (years) }\end{array}$ & & & \\
\hline & & & $\begin{array}{l}\text { Aversion to GMO } \\
\text { (dummy) }\end{array}$ & & & \\
\hline
\end{tabular}

Notes: (1) test Value column refers to $t$-Student test for difference between means of the class and the mean of the period when the variable is continuous, and to $\chi^{2}$ test when variable is discrete (e.g. Aversion to GMO). Significance

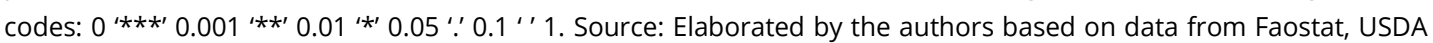
reports and World Bank.

\section{Period II (1996-2005)}

As expected, the first GMO commercial release during Period II caused significant changes in the soybean trade pattern. Variables labt (labeling time) and aver (aversion to GMO) were included into models. Factors 1, 2 and 3 accounted for $67.22 \%$ of the accumulated variance. KMO and Bartlett's test estimated acceptable values, MSA $=0.63$ and p-value $<0.01$. The analysis was performed on 126 individuals, described by 10 variables (Table 1).

Factor 1 is marked by high loadings on variables that stand for labeling time and aversion to GMO. Therefore, it may be renamed as "anti-GMO markets II". Note that, Brazilian share has high loading on and is positively correlated with these markets. On the contrary, the US and AR exports are negatively correlated to the same factor. It is worth noting that markets that developed GMO-aversion and adopted mandatory labeling were also those facing poor impetus of demand. Once again, factor 2 or "Brazil's Price Premiums II" is discernible by high loadings on premiums, but contrary to the results from Period I, US exports get high and negative loading on factor 2. However, when one looks over the Brazilian share behavior on factor 2, it can be seen that it is also negatively correlated with "Brazil's Price Premiums II". Therefore, when jointly considered, factor 1 indicates that Brazil gained market shares in "anti-GMO markets II" but without average price premium, always proxied by TUVs. Finally, even if with lower factor loadings, factor 3 interpretation reinforces some relations found on factor 1, i.e., the US and AR exports are related to the importance of soybeans in importing markets (Table 2 and Figure $1 \mathrm{~b}$ ).

In the HCA analysis, by cutting the dendrogram at a height of 30, 4 groups were obtained (Table 4 and Figure $2 b$ ). Group 1 is made up of 4 entities and is marked by Brazil's premiums. Then, let group 1 be named as "Brothers of Brazil II". It is worth noting that "Brothers of Brazil II" strongly oppose to large imports from the US and AR. Also, note that it is not possible to say that this small group mostly imported soybean from Brazil, since Brazilian shares grew into a different direction. South Africa, Switzerland and Sweden are countries that make part of "Brothers of Brazil II", but only Switzerland (02) and Sweden (04) have paid premiums and chiefly imported soybeans from Brazil at the same time ${ }^{11}$.

\footnotetext{
${ }^{11}$ In accordance with results, a number of works put these countries as a group that managed high levels of hatred during the period.
} 
Group 2 consists of 38 entities. This group can be told apart by the relative importance of soybean, high imports coming from Argentina, small Brazilian share, low income, no aversion to GMO and short or none labeling time. Thus, group 2 will be named as "Friends of Argentina II". Countries in northern Africa, Latin America, Asia and low-income countries in Europe are examples of markets that came together in the "Friends of Argentina II" group. Group 3, instead, is made up of 41 entities. Countries were grouped essentially because of high-income levels, no aversion, more years under mandatory labeling rules and large Brazilian market shares. Thus, it is convenient to name it as "Friends of Brazil II". In this group, one could find countries such as United Arab Emirates, high-income countries in Europe and South Korea. Note that Brazilian share is meaningfully large in these markets but there is no evidence to say that "Friends of Brazil II" paid price premiums during this period. Finally, group 4 is defined by high level of aversion, high income and reduced volume of imports from Argentina. To name such a group as friend of a particular exporter is ambiguous. There is low significance level and negative signal on variables standing for US and AR exports and Brazil market shares. Thus, reduced volumes of imports from Argentina are the sole relation that can be drawn - this group was named as "Enemies of Argentina II". This group consists of high-income countries in Europe, in particular countries out of the Eurozone ${ }^{12}$, Japan and Mexico. Looking into dataset figures on US and BR exports, one could assume that these markets were, somewhat, shared by US and BR exports during that period.

Table 4. Characteristics of classes of soybean trade entities (country/year), Period II (1996-2004)

\begin{tabular}{|c|c|c|c|c|c|c|c|}
\hline \multirow[b]{2}{*}{ Cluster } & \multirow{2}{*}{$\begin{array}{c}\text { Observations } \\
\text { Countries \& } \\
\text { Years }\end{array}$} & \multirow{2}{*}{$\begin{array}{l}\text { Cluster } \\
\text { Name }\end{array}$} & \multicolumn{5}{|c|}{ Descriptive Statistics } \\
\hline & & & \multirow{2}{*}{$\begin{array}{c}\text { Variable } \\
\text { Imports from } \\
\text { Argentina LN(ton) }\end{array}$} & \multirow{2}{*}{$\begin{array}{l}\text { Mean } \\
11.32\end{array}$} & \multirow{2}{*}{$\begin{array}{c}\begin{array}{c}\text { Standard } \\
\text { Deviation }\end{array} \\
1.45\end{array}$} & \multicolumn{2}{|c|}{$\begin{array}{c}\text { test } \\
\text { Value }^{(1)}\end{array}$} \\
\hline \multirow{11}{*}{$\begin{array}{c}1 \\
(n=38)\end{array}$} & \multirow{11}{*}{$\begin{array}{c}\text { Colombia } \\
(97,98,00,04) \\
\text { Egypt } \\
(97,00,01,04) \\
\text { Israel }(03,04) \\
\text { Malaysia } \\
(98,00,01,02, \\
\text { 03, 04) } \\
\text { Mexico }(98,02) \\
\text { Morocco }(01) \\
\text { Philippines } \\
(01,02) \\
\text { Portugal }(96) \\
\text { Spain }(96,97,98) \\
\text { Syria }(04) \\
\text { Thailand }(98,00, \\
\text { 01, 02, 03, 04) } \\
\text { Turkey }(96,98, \\
\text { 00, 02, 03, 04) }\end{array}$} & \multirow{11}{*}{$\begin{array}{l}\text { Friends of } \\
\text { Argentina II }\end{array}$} & & & & 3.51 & 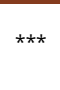 \\
\hline & & & $\begin{array}{l}\text { Imports from USA } \\
\text { LN(ton) }\end{array}$ & 12.59 & 1.00 & 0.89 & \\
\hline & & & $\begin{array}{l}\text { Share of soybean/ } \\
\text { agr. imports }\end{array}$ & 0.05 & 0.03 & 3.61 & $\star \star \star$ \\
\hline & & & $\begin{array}{l}\text { Share of Brazilian } \\
\text { soybean imports }\end{array}$ & 0.12 & 0.12 & $\begin{array}{c}- \\
4.88\end{array}$ & $\star \star *$ \\
\hline & & & $\begin{array}{l}\text { Premium Brazil/ } \\
\text { Argentina (ratio) }\end{array}$ & 1.03 & 0.07 & 1.07 & \\
\hline & & & $\begin{array}{c}\text { Premium Brazil/ USA } \\
\text { (ratio) }\end{array}$ & 0.99 & 0.14 & 0.44 & \\
\hline & & & $\begin{array}{l}\text { Premium Brazil/ } \\
\text { mean (ratio) }\end{array}$ & 1.00 & 0.06 & $\begin{array}{l}- \\
1.35\end{array}$ & \\
\hline & & & $\begin{array}{l}\text { PPP per capita } \\
\text { LN(USD/year) }\end{array}$ & 8.90 & 0.58 & $\begin{array}{c}- \\
6.93\end{array}$ & $\star \star \star$ \\
\hline & & & $\begin{array}{l}\text { Growth rate of agr. } \\
\text { imports (\%) }\end{array}$ & - & - & - & \\
\hline & & & $\begin{array}{c}\text { GMO labeling time } \\
\text { (years) }\end{array}$ & 0.11 & 0.39 & $\begin{array}{c}- \\
5.43\end{array}$ & $\star * \star$ \\
\hline & & & $\begin{array}{l}\text { Aversion to GMO } \\
\text { (dummy) }\end{array}$ & 0.00 & 0.00 & $\begin{array}{c}- \\
4.33\end{array}$ & $\star \star *$ \\
\hline $\begin{array}{c}2 \\
(n=4)\end{array}$ & $\begin{array}{l}\text { South Africa (03) } \\
\text { Sweden (04) }\end{array}$ & $\begin{array}{c}\text { Brothers of } \\
\text { Brazil II }\end{array}$ & $\begin{array}{c}\text { Imports from } \\
\text { Argentina LN(ton) }\end{array}$ & 6.84 & 2.20 & $\begin{array}{c}- \\
2.53\end{array}$ & * \\
\hline
\end{tabular}

\footnotetext{
${ }^{12}$ Oliveira et al. (2012) pointed out that Europeans countries out of European Union usually enacted even more
} prohibitive regulatory frameworks when compared to member's states. 
Table 4. Continued...

\begin{tabular}{|c|c|c|c|c|c|c|c|}
\hline \multirow[b]{2}{*}{ Cluster } & \multirow{2}{*}{$\begin{array}{l}\text { Observations } \\
\text { Countries \& } \\
\text { Years }\end{array}$} & \multirow{2}{*}{$\begin{array}{l}\text { Cluster } \\
\text { Name }\end{array}$} & \multicolumn{5}{|c|}{ Descriptive Statistics } \\
\hline & & & \multirow{2}{*}{$\begin{array}{c}\text { Variable } \\
\text { Imports from USA } \\
\text { LN(ton) }\end{array}$} & \multirow{2}{*}{$\begin{array}{l}\text { Mean } \\
5.63\end{array}$} & \multirow{2}{*}{$\begin{array}{c}\begin{array}{c}\text { Standard } \\
\text { Deviation }\end{array} \\
3.64\end{array}$} & \multicolumn{2}{|c|}{$\begin{array}{c}\text { test } \\
\text { Value }^{(1)}\end{array}$} \\
\hline & $\begin{array}{c}\text { Switzerland } \\
(01,02)\end{array}$ & & & & & $\begin{array}{c}- \\
5.17\end{array}$ & $\star * *$ \\
\hline & & & $\begin{array}{l}\text { Share of soybean/ } \\
\text { agr. imports }\end{array}$ & 0.00 & 0.00 & 2.19 & * \\
\hline & & & $\begin{array}{l}\text { Share of Brazilian } \\
\text { soybean imports }\end{array}$ & 0.33 & 0.38 & 0.05 & \\
\hline & & & $\begin{array}{l}\text { Premium Brazil/ } \\
\text { Argentina (ratio) }\end{array}$ & 1.66 & 0.97 & 4.53 & $\star * \star$ \\
\hline & & & $\begin{array}{l}\text { Premium Brazil/ USA } \\
\text { (ratio) }\end{array}$ & 1.83 & 0.36 & 7.32 & $\star \star \star *$ \\
\hline & & & $\begin{array}{l}\text { Premium Brazil/ } \\
\text { mean (ratio) }\end{array}$ & 2.38 & 0.70 & 8.94 & $\star \star \star$ \\
\hline & & & $\begin{array}{l}\text { PPP per capita } \\
\text { LN(USD/year) }\end{array}$ & 10.01 & 0.73 & 0.75 & \\
\hline & & & $\begin{array}{l}\text { Growth rate of agr. } \\
\text { imports (\%) }\end{array}$ & - & - & - & \\
\hline & & & $\begin{array}{c}\text { GMO labeling time } \\
\text { (years) }\end{array}$ & 5.50 & 3.70 & 2.14 & * \\
\hline & & & $\begin{array}{l}\text { Aversion to GMO } \\
\text { (dummy) }\end{array}$ & 0.75 & 0.50 & 1.73 & . \\
\hline \multirow{11}{*}{$\begin{array}{c}3 \\
(n=41)\end{array}$} & \multirow{5}{*}{$\begin{array}{c}\text { Arab Emirates } \\
(04) \\
\text { Belgium }(00,01 \\
02,03,04) \\
\text { Denmark (98) } \\
\text { Great Britain }(96, \\
97,98,00,01,02 \\
03,04)\end{array}$} & \multirow{11}{*}{$\begin{array}{l}\text { Friends of } \\
\text { Brazil II }\end{array}$} & $\begin{array}{c}\text { Imports from } \\
\text { Argentina LN(ton) }\end{array}$ & 10.08 & 1.79 & 0.47 & \\
\hline & & & $\begin{array}{c}\text { Imports from USA } \\
\text { LN(ton) }\end{array}$ & 12.54 & 0.89 & 0.81 & \\
\hline & & & $\begin{array}{l}\text { Share of soybean/ } \\
\text { agr. imports }\end{array}$ & 0.02 & 0.02 & 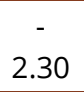 & * \\
\hline & & & $\begin{array}{l}\text { Share of Brazilian } \\
\text { soybean imports }\end{array}$ & 0.46 & 0.21 & 2.88 & ** \\
\hline & & & $\begin{array}{l}\text { Premium Brazil/ } \\
\text { Argentina (ratio) }\end{array}$ & 0.94 & 0.15 & 0.93 & \\
\hline & $\begin{array}{c}\text { Greece }(97,98, \\
00,01,02,03,04)\end{array}$ & & $\begin{array}{c}\text { Premium Brazil/ USA } \\
\text { (ratio) }\end{array}$ & 1.00 & 0.16 & - & \\
\hline & $\begin{array}{l}\text { Italy }(96,97,98, \\
00,01,02,03,04)\end{array}$ & & $\begin{array}{l}\text { Premium Brazil/ } \\
\text { mean (ratio) }\end{array}$ & 0.99 & 0.04 & 1.43 & \\
\hline & $\begin{array}{c}\text { 02, 03) } \\
\text { Romania (02) }\end{array}$ & & $\begin{array}{l}\text { PPP per capita } \\
\text { LN(USD/year) }\end{array}$ & 10.05 & 0.27 & 2.73 & ** \\
\hline & $\begin{array}{l}\text { South Korea (03) } \\
\text { Spain }(00,01,02,\end{array}$ & & $\begin{array}{l}\text { Growth rate of agr. } \\
\text { imports (\%) }\end{array}$ & - & - & - & \\
\hline & $03,04)$ & & $\begin{array}{c}\text { GMO labeling time } \\
\text { (years) }\end{array}$ & 3.71 & 2.36 & 2.51 & * \\
\hline & & & $\begin{array}{l}\text { Aversion to GMO } \\
\text { (dummy) }\end{array}$ & 0.00 & 0.00 & 4.50 & $\star \star \star *$ \\
\hline \multirow{3}{*}{$\begin{array}{c}4 \\
(n=43)\end{array}$} & \multirow{3}{*}{$\begin{array}{c}\text { Chile }(00) \\
\text { Denmark }(01,02) \\
\text { France }(96,98, \\
00,01,02,04)\end{array}$} & \multirow{3}{*}{$\begin{array}{c}\text { Enemies of } \\
\text { Argentina } \\
\text { II }\end{array}$} & $\begin{array}{c}\text { Imports from } \\
\text { Argentina LN(ton) }\end{array}$ & 8.73 & 2.73 & - & ** \\
\hline & & & $\begin{array}{c}\text { Imports from USA } \\
\text { LN(ton) }\end{array}$ & 12.20 & 3.37 & 0.03 & \\
\hline & & & $\begin{array}{c}\text { Share of soybean/ } \\
\text { agr. imports }\end{array}$ & 0.03 & 0.03 & $\begin{array}{c}- \\
0.77\end{array}$ & \\
\hline
\end{tabular}


Table 4. Continued...

\begin{tabular}{|c|c|c|c|c|c|c|}
\hline \multirow[b]{2}{*}{ Cluster } & \multirow{2}{*}{$\begin{array}{c}\text { Observations } \\
\text { Countries \& } \\
\text { Years }\end{array}$} & \multirow{2}{*}{$\begin{array}{l}\text { Cluster } \\
\text { Name }\end{array}$} & \multicolumn{4}{|c|}{ Descriptive Statistics } \\
\hline & & & Variable & Mean & $\begin{array}{l}\text { Standard } \\
\text { Deviation }\end{array}$ & $\begin{array}{c}\text { test } \\
\text { Value }^{(1)}\end{array}$ \\
\hline & \multirow{3}{*}{$\begin{array}{c}\text { Germany }(96,97, \\
98,00,01,02,03, \\
04) \\
\text { Ireland }(00,01 \\
02) \\
\text { Japan }(96,97,98 \\
00,01,02,03,04)\end{array}$} & & $\begin{array}{l}\text { Share of Brazilian } \\
\text { soybean imports }\end{array}$ & 0.40 & 0.27 & 1.40 \\
\hline & & & $\begin{array}{l}\text { Premium Brazil/ } \\
\text { Argentina (ratio) }\end{array}$ & 0.92 & 0.23 & $\begin{array}{c}- \\
1.48\end{array}$ \\
\hline & & & $\begin{array}{c}\text { Premium Brazil/ USA } \\
\text { (ratio) }\end{array}$ & 0.95 & 0.15 & $\begin{array}{c}- \\
1.64\end{array}$ \\
\hline & \multirow{5}{*}{$\begin{array}{c}\text { Mexico (03) } \\
\text { Norway }(96) \\
\text { Sweden }(02,03) \\
\text { Switzerland }(00, \\
03,04) \\
\text { The Netherlands } \\
(96,97,98,00, \\
01)\end{array}$} & & $\begin{array}{l}\text { Premium Brazil/ } \\
\text { mean (ratio) }\end{array}$ & 1.05 & 0.11 & 0.24 \\
\hline & & & $\begin{array}{l}\text { PPP per capita } \\
\text { LN(USD/year) }\end{array}$ & 10.19 & 0.24 & $4.11 \quad * \star *$ \\
\hline & & & $\begin{array}{l}\text { Growth rate of agr. } \\
\text { imports (\%) }\end{array}$ & - & - & - \\
\hline & & & $\begin{array}{c}\text { GMO labeling time } \\
\text { (years) }\end{array}$ & 3.23 & 2.77 & 1.48 \\
\hline & & & $\begin{array}{l}\text { Aversion to GMO } \\
(\text { dummy })\end{array}$ & 0.91 & 0.29 & $7.46 \quad \star * *$ \\
\hline
\end{tabular}

Notes: ${ }^{(1)}$ test Value column refers to $t$-Student test for difference between means of the class and the mean of the period when the variable is continuous, and to $\chi^{2}$ test when variable is discrete (e.g. Aversion to GMO). Significance

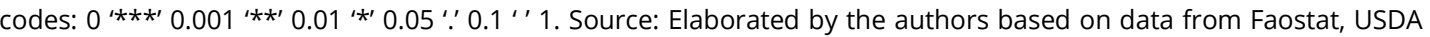
reports and World Bank.

\section{Period III (2005-2010)}

Finally, in Period III some changes related to the emergence of dual-market system continued and others reverted. The Brazilian official adoption of GMO technology in 2005 and its rapid technology adoption are the new facts to be taken into account from 2005 on. Factors 1,2 and 3 accounted for $68.15 \%$ of accumulated variance. KMO and Bartlett's tests estimated acceptable values, MSA=0.64 and $p<0.01$. The analysis was performed on 101 individuals and described by 11 variables (Table 1 ).

Factor 1 is marked by high loadings on growth rate of agricultural imports and relative importance of soybean, thus, let it be named as "Booming Markets III" (Table 2). Argentina exports are once again positively correlated with "Booming Markets III" but, surprisingly, US exports have only small loadings on this factor. Just as in the Period II, Brazil's share of soybeans market is negatively correlated with "Booming Markets III". As expected, mandatory labeling, aversion to GMO and high income are also negatively correlated with "Booming Markets III" and positively correlated with Brazilian market shares. Note that premiums for Brazilian soybean over those from Argentina come to factor 1 with a positive correlation. Once again, it means that Brazil's share of soybean market is reduced when Brazilian prices are higher than Argentinean prices. Factor 2 is defined by Brazilian premiums but at this time only by premiums over prices in other Brazilian markets and over US price of exports in the same markets, since premiums over Argentina have higher loadings in factor 1 . Then, let factor 2 be renamed as "Brazil Premiums-BR-US III. Argentinean exports and soybeans relative importance are negatively correlated with "Brazilian Premiums-BR-US III", meaning that in the presence of premiums (BR-US) the AR exports and soybeans relative importance are reduced. Once again, there is no evidence to say that Brazilian share expanded into those markets. But we could say that in presence of premiums for Brazilian soybeans - in relation to US prices -, Argentinean shares of market are reduced. It may be indicating that these markets have "revealed preferences" for IP soybeans, and then price premiums could be guaranteeing production of certain quantity of conventional crops - since Argentinean adoption rate was virtually $100 \%$ at this time. 
Factor 3, marked by high loadings on US exports, brings a seemingly counterintuitive result. Let factor 3 be named as "US exports". Surprisingly, aversion to GMO is positively correlated with US exports. It points to the fact that US managed to increase exports into markets with technology hatred, in spite of the US soybeans being often perceived as GM. The aforesaid may suggest that given the poor infrastructure to segregate as well as the rapid diffusion of technology in Brazil the image of Free-GMO country put up during the prior decade has been dismissed - in consonance with findings in Foster (2010).

From the HCA, 4 groups are obtained (Table 5 and Figure 2c). Group 1 comprises 35 entities and is better described by low rates of growth of agricultural imports, longer labeling time, decreased volume of US exports, larger Brazilian shares and reduced premium over US (rusa). This group can be renamed as "Friends of Brazil III". Latin America neighbors, some European countries and Saudi Arabia make part of this group. It is worth pointing out some interchanges of countries across the groups when we compare Period II with Period III. Taking into consideration "Friends of Brazil II", in particular, it is possible to see that United Arab Emirates migrated to "Friends of Argentina III". Denmark, before in "Friends of Brazil II" group, also migrated but to the "Brothers of Brazil III" group. In other words, it is possible to say that some countries may have changed their position regarding the level of hatred and/or conditions of international supply, expressing a type of "substitution effect", i.e. changes in relative prices affecting consumer choice, and also a higher equilibrium price in IP market since marginal costs may increase via IP costs, as verified by the literature. Group 2 is made up of 16 entities that maintain high aversion to GMO, longer labeling time, high levels of income, decreased AR imports and high imports from US. Then, group 2 can be named as "US Friends III". This group consists of Germany, France (09) ${ }^{13}$, Ireland (07) ${ }^{14}$, Japan and The Netherlands. Bilateral trade agreements likely play a key role on the formation of this group. Moreover, "Friends of US III" are made up of countries previously named as "Enemies of Argentina II". "Enemies of Argentina II" were considerably regrouped into "Friends of US III" and "Friends and Brother of Brazil III", partially because of some entities were cut off from dataset on account of the missing data. This suggests that markets with high levels of hatred opposed to Argentinean soy but imported from Brazil and US.

Group 3 is made up of 35 entities and is better described by high growth rates of agricultural imports, no aversion to GMO, short or none labeling time, low income levels, reduced market share for Brazilian soybeans and, as expected, increased volume of AR imports. It makes sense that this group can be named as "Friends of Argentina III". Countries in northern Africa, Israel, Iran, Syria, Turkey and Asian developing economies are in this group.

Finally, Group 4, with 15 entities, is the group marked by Brazilian premiums (rmbr, rusa and rarg), reduced Brazil share and minor soybeans relative importance. The "Brothers of Brazil III" consists of Belgium (05), Canada (05, 09), Denmark (07), Ireland (10), Mexico (06), Malaysia $(08,10)$, Philippines $(07,08,09,10)$ and Singapore $(08,09,10)$. Composition of this group changed completely when compared to "Brothers of Brazil II".

In sum, results point out to changes in international trade that may be straight related to the pace of technology adoption across producing countries. Brazil, Argentina and US specialized in supplying different markets under different marketing conditions. Period II, in particular, make more evident that late GM-technology adoption by Brazil set the basis of a dual-market system. The Brazilian share of the soybean market increased in those markets with mandatory labeling rules and averse to the technology. However, premiums are only verified in those markets that the Brazilian share is smaller. This specialization started before the introduction of GM-soybeans into market chains, but was clearly intensified after 1996. The rapid pace of technology adoption in Brazil, however, changed the previous equilibrium. On the one hand, price premiums became more prominent, which is coherent with some estimates of increasing relative prices reported by empirical literature. On the other hand, from the PCA analysis, one can see that US exports are now related to technology aversion. However, HCA indicates that Brazilian shares remains high in those markets with more time of mandatory labeling and high income.

\footnotetext{
${ }^{13 " 09 "}$ means the observation made in 2009.
}

14"07" means the observation made in 2007. 
Based on the findings afore presented and, on the literature, we could draw a central hypothesis to be verified in the econometric model: after technology adoption, Brazil's share of international market of soybeans increased in markets under mandatory labeling regime but premiums were not large enough to be perceived from a national level. Moreover, mandatory labeling regime is positively correlated with high income and negatively correlated with booming markets.

Table 5. Characteristics of classes of soybean trade entities (country/year), Period III (2005-2010)

\begin{tabular}{|c|c|c|c|c|c|c|c|}
\hline \multirow[b]{2}{*}{ Cluster } & \multirow{2}{*}{$\begin{array}{c}\text { Observations } \\
\text { Countries \& } \\
\text { Years }\end{array}$} & \multirow{2}{*}{$\begin{array}{l}\text { Cluster } \\
\text { Features }\end{array}$} & \multicolumn{5}{|c|}{ Descriptive Statistics } \\
\hline & & & Variable & Mean & $\begin{array}{l}\text { Standard } \\
\text { Deviation }\end{array}$ & & \\
\hline \multirow{11}{*}{$\begin{array}{c}1 \\
(n=16)\end{array}$} & \multirow{11}{*}{$\begin{array}{c}\text { France }(09) \\
\text { Germany }(05,06, \\
07,08,09,10) \\
\text { Ireland }(07) \\
\text { Japan }(07,08, \\
09,10) \\
\text { The Netherlands } \\
(05,07,09,10)\end{array}$} & \multirow{11}{*}{$\begin{array}{l}\text { Friends } \\
\text { of US III }\end{array}$} & $\begin{array}{l}\text { Imports from Argentina } \\
\text { LN(ton) }\end{array}$ & 6.57 & 1.87 & 3.33 & ** \\
\hline & & & Imports from USA LN(ton) & 13.22 & 1.72 & 2.37 & * \\
\hline & & & $\begin{array}{l}\text { Share of soybean/ agr. } \\
\text { imports }\end{array}$ & 0.03 & 0.01 & 1.19 & \\
\hline & & & $\begin{array}{l}\text { Share of Brazilian soybean } \\
\text { imports }\end{array}$ & 0.53 & 0.32 & 1.09 & \\
\hline & & & $\begin{array}{c}\text { Premium Brazil/ Argentina } \\
\text { (ratio) }\end{array}$ & 0.72 & 0.15 & 4.03 & $* \star \star$ \\
\hline & & & $\begin{array}{c}\text { Premium Brazil/ USA } \\
\text { (ratio) }\end{array}$ & 0.97 & 0.11 & 0.36 & \\
\hline & & & $\begin{array}{l}\text { Premium Brazil/ mean } \\
\text { (ratio) }\end{array}$ & 0.98 & 0.06 & 1.63 & \\
\hline & & & $\begin{array}{l}\text { PPP per capita } \\
\text { LN(USD/year) }\end{array}$ & 10.48 & 0.10 & 3.23 & $\star \star$ \\
\hline & & & $\begin{array}{l}\text { Growth rate of agr. } \\
\text { imports (\%) }\end{array}$ & 7.97 & 2.19 & 2.42 & * \\
\hline & & & GMO labeling time (years) & 10.13 & 1.89 & 3.59 & $\star \star \star$ \\
\hline & & & Aversion to GMO (dummy) & 1.00 & 0.00 & 8.52 & $\star \star \star$ \\
\hline \multirow{11}{*}{$\begin{array}{c}2 \\
(n=35)\end{array}$} & \multirow{11}{*}{$\begin{array}{c}\text { Belgium }(06,07, \\
\text { 08) } \\
\text { Bolivia }(06) \\
\text { Great Britain }(05, \\
\text { 06, 07, 08,10) } \\
\text { Greece }(05,06, \\
\text { 07, 08, 09,10) } \\
\text { Italy }(05,06,07, \\
\text { 08, 09,10) } \\
\text { Paraguay }(06) \\
\text { Portugal }(07,08) \\
\text { Saudi Arabia }(07, \\
09,10) \\
\text { Spain }(05,07,08, \\
09,10) \\
\text { Sweden }(05) \\
\text { Uruguay }(09)\end{array}$} & \multirow{11}{*}{$\begin{array}{l}\text { Friends } \\
\text { of Brazil } \\
\text { III }\end{array}$} & $\begin{array}{l}\text { Imports from Argentina } \\
\text { LN(ton) }\end{array}$ & 8.67 & 2.10 & 0.49 & \\
\hline & & & Imports from USA LN(ton) & 9.75 & 3.28 & 3.08 & $\star \star$ \\
\hline & & & $\begin{array}{l}\text { Share of soybean/ agr. } \\
\text { imports }\end{array}$ & 0.02 & 0.03 & 1.95 & $\cdot$ \\
\hline & & & $\begin{array}{l}\text { Share of Brazilian soybean } \\
\text { imports }\end{array}$ & 0.75 & 0.23 & 4.98 & $\star \star \star$ \\
\hline & & & $\begin{array}{c}\text { Premium Brazil/ Argentina } \\
\text { (ratio) }\end{array}$ & 0.91 & 0.24 & 1.34 & \\
\hline & & & $\begin{array}{l}\text { Premium Brazil/ USA } \\
\text { (ratio) }\end{array}$ & 0.86 & 0.22 & 2.74 & $\star \star$ \\
\hline & & & $\begin{array}{c}\text { Premium Brazil/ mean } \\
\text { (ratio) }\end{array}$ & 1.03 & 0.24 & 1.05 & \\
\hline & & & $\begin{array}{l}\text { PPP per capita } \\
\text { LN(USD/year) }\end{array}$ & 10.14 & 0.50 & 2.14 & * \\
\hline & & & $\begin{array}{l}\text { Growth rate of agr. } \\
\text { imports (\%) }\end{array}$ & 7.03 & 3.60 & $\begin{array}{c}- \\
4.22\end{array}$ & $\star \star \star$ \\
\hline & & & GMO labeling time (years) & 9.14 & 3.35 & 3.94 & $\star \star \star *$ \\
\hline & & & Aversion to GMO (dummy) & 0.03 & 0.17 & 2.22 & * \\
\hline
\end{tabular}


Table 5. Continued...

\begin{tabular}{|c|c|c|c|c|c|c|c|}
\hline \multirow{2}{*}{ Cluster } & \multirow{2}{*}{$\begin{array}{c}\text { Observations } \\
\text { Countries \& } \\
\text { Years }\end{array}$} & \multirow{2}{*}{$\begin{array}{l}\text { Cluster } \\
\text { Features }\end{array}$} & \multicolumn{5}{|c|}{ Descriptive Statistics } \\
\hline & & & Variable & Mean & $\begin{array}{l}\text { Standard } \\
\text { Deviation }\end{array}$ & $\begin{aligned} t \\
\mathrm{Val}\end{aligned}$ & $\begin{array}{l}t \\
e^{(1)}\end{array}$ \\
\hline \multirow{11}{*}{$\begin{array}{c}3 \\
(n=15)\end{array}$} & \multirow{11}{*}{$\begin{array}{c}\text { Belgium }(05) \\
\text { Canada }(05,09) \\
\text { Denmark }(07) \\
\text { Ireland }(10) \\
\text { Malaysia }(08,10) \\
\text { Mexico }(06) \\
\text { Philippines }(07, \\
\text { 08, 09,10) } \\
\text { Singapore }(08, \\
\text { 09,10) }\end{array}$} & \multirow{11}{*}{$\begin{array}{c}\text { Brothers } \\
\text { of Brazil } \\
\text { III }\end{array}$} & $\begin{array}{l}\text { Imports from Argentina } \\
\text { LN(ton) }\end{array}$ & 7.06 & 2.71 & $\begin{array}{c}- \\
2.47\end{array}$ & * \\
\hline & & & Imports from USA LN(ton) & 11.18 & 1.98 & $0 . \overline{4}$ & \\
\hline & & & $\begin{array}{l}\text { Share of soybean/ agr. } \\
\text { imports }\end{array}$ & 0.01 & 0.02 & 2.92 & $\star \star$ \\
\hline & & & $\begin{array}{c}\text { Share of Brazilian soybean } \\
\text { imports }\end{array}$ & 0.05 & 0.10 & $\begin{array}{c}- \\
4.09\end{array}$ & $\star * *$ \\
\hline & & & $\begin{array}{c}\text { Premium Brazil/ Argentina } \\
\text { (ratio) }\end{array}$ & 1.26 & 0.26 & 3.94 & $\star \star \star *$ \\
\hline & & & $\begin{array}{l}\text { Premium Brazil/ USA } \\
\text { (ratio) }\end{array}$ & 1.43 & 0.25 & 6.00 & $* \star *$ \\
\hline & & & $\begin{array}{c}\text { Premium Brazil/ mean } \\
\text { (ratio) }\end{array}$ & 1.51 & 0.27 & 5.94 & $\star \star *$ \\
\hline & & & $\begin{array}{l}\text { PPP per capita } \\
\text { LN(USD/year) }\end{array}$ & 9.77 & 1.07 & $\begin{array}{c}- \\
0.27\end{array}$ & \\
\hline & & & $\begin{array}{l}\text { Growth rate of agr. } \\
\text { imports (\%) }\end{array}$ & 12.28 & 4.52 & 0.11 & \\
\hline & & & GMO labeling time (years) & 2.07 & 4.38 & $\begin{array}{c}- \\
2.54\end{array}$ & * \\
\hline & & & Aversion to GMO (dummy) & 0.07 & 0.26 & $\begin{array}{c}- \\
1.09\end{array}$ & \\
\hline \multirow{11}{*}{$\begin{array}{c}4 \\
(n=35)\end{array}$} & & \multirow{11}{*}{$\begin{array}{l}\text { Friends } \\
\text { of } \\
\text { Argentina } \\
\text { III }\end{array}$} & $\begin{array}{l}\text { Imports from Argentina } \\
\text { LN(ton) }\end{array}$ & 11.04 & 2.00 & 4.23 & $* * *$ \\
\hline & Colombia & & Imports from USA LN(ton) & 12.64 & 1.80 & 2.23 & * \\
\hline & $\begin{array}{c}(05,08,09) \\
\text { Egypt }\end{array}$ & & $\begin{array}{c}\text { Share of soybean/ agr. } \\
\text { imports }\end{array}$ & 0.06 & 0.03 & 4.40 & $\star \star *$ \\
\hline & $\begin{array}{l}(05,07,08,09) \\
\text { Indonesia }(08,10)\end{array}$ & & $\begin{array}{c}\text { Share of Brazilian soybean } \\
\text { imports }\end{array}$ & 0.23 & 0.22 & $\begin{array}{c}- \\
3.20\end{array}$ & $* *$ \\
\hline & $\begin{array}{c}\text { Israel } \\
(05,07,08)\end{array}$ & & $\begin{array}{c}\text { Premium Brazil/ Argentina } \\
\text { (ratio) }\end{array}$ & 1.05 & 0.14 & 1.48 & \\
\hline & $\begin{array}{l}\text { Malaysia }(07) \\
\text { Mexico }(05,07)\end{array}$ & & $\begin{array}{l}\text { Premium Brazil/ USA } \\
\text { (ratio) }\end{array}$ & 0.96 & 0.15 & $\begin{array}{c}- \\
0.84\end{array}$ & \\
\hline & $\begin{array}{c}\text { Syria (06) } \\
\text { Thailand }(05,06\end{array}$ & & $\begin{array}{l}\text { Premium Brazil/ mean } \\
\text { (ratio) }\end{array}$ & 1.00 & 0.10 & 1.84 & . \\
\hline & $\begin{array}{c}07,08,09,10) \\
\text { Turkey }(05,06,07,\end{array}$ & & $\begin{array}{l}\text { PPP per capita } \\
\text { LN(USD/year) }\end{array}$ & 9.26 & 0.69 & $\begin{array}{c}- \\
3.81\end{array}$ & $\star * *$ \\
\hline & $\begin{array}{c}\text { 08, 09,10) } \\
\text { United Arab }\end{array}$ & & $\begin{array}{l}\text { Growth rate of agr. } \\
\text { imports (\%) }\end{array}$ & 18.93 & 5.25 & 5.46 & $* \star *$ \\
\hline & $(05,06,07)$ & & GMO labeling time (years) & 1.34 & 2.63 & $\begin{array}{c}- \\
4.72\end{array}$ & $\star \star * *$ \\
\hline & & & Aversion to GMO (dummy) & 0.00 & 0.00 & $\begin{array}{c}- \\
2.73\end{array}$ & ** \\
\hline
\end{tabular}

Notes: (1) test Value column refers to $t$-Student test for difference between means of the class and the mean of the period when the variable is continuous, and to $\chi^{2}$ test when variable is discrete (e.g. Aversion to GMO). Significance

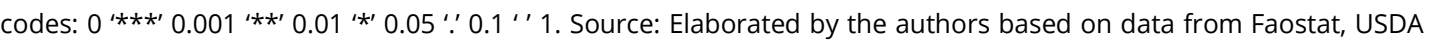
reports and World Bank. 


\subsection{Random Effects Model}

Seeking to verify the market shares gain and premium pricing hypotheses afore defined, we ran a Random Effects Models on data from 1996-2010 setting Brazil's share of soybeans $(s b r 3)$ as the dependent variable. Results are shown in Table 6 . Wald $\chi^{2}$ values indicated that the coefficients in the model are different than zero. More than $65 \%$ of the variability of residuals is due to the heterogeneity of importing countries $(\rho)$.

It is important to note that aversion to GMO-technology (aver) and years under mandatory labeling regime (labt) differs in signal and significance, indicating that markets with usually identified as averse by the literature are not necessarily the same markets which enacted mandatory labeling rules. Variables spppc, aver and ssoy are not significant at the level of 0.10 , thus, they are inconclusive to explain Brazilian shares (sbr3).

Variables labt and stimp are significant at a level of $\mathrm{p}<0.001$ and $r m b r$ at a level of $\mathrm{p}<0.10$. Overall, it can be observed that time under mandatory labeling regime increased Brazilian share and growth of agricultural imports and higher Brazilian soy prices decreased market shares (as expected in model specification). The results corroborate the hypothesis that Brazilian market share increased in markets under mandatory labeling regimes and decreased in booming markets, as also drawn from multivariate methods. On the other hand, the hypothesis of premiums for Brazilian soybean can be rejected, since the coefficient of $r m b r$ has negative signal. Furthermore, results are aligned with simulating models that considered that depending on the size of the markets - and seed market structure (Desquilbet \& Bullock 2009) -, relative prices could be equal to 1 .

Table 6. Random effects GLS regression results ( $n=479,69$ importing countries), taking Brazilian share in soybean market as dependent variable, from 1996 to 2010

\begin{tabular}{|c|c|c|c|c|c|c|}
\hline \multirow{2}{*}{ Independent Variables } & \multicolumn{6}{|c|}{$\begin{array}{c}\text { Coefficients } \\
\text { (Standard errors) }\end{array}$} \\
\hline & (1) & & (2) & & (3) & \\
\hline \multirow[t]{2}{*}{ Aversion to GMO (dummy) } & -0.1170 & & -0.1088 & & -0.0692 & \\
\hline & $(0.0907)$ & & $(0.0905)$ & & $(0.0828)$ & \\
\hline \multirow[t]{2}{*}{ GMO labeling time (years) } & 0.0338 & $* \star \star$ & 0.0336 & $* * *$ & 0.0459 & $* \star \star$ \\
\hline & $(0.0044)$ & & $(0.0044)$ & & $(0.0061)$ & \\
\hline \multirow[t]{2}{*}{ Premium Brazil/ mean (ratio) } & & & -0.1269 & $\cdot$ & -0.1326 & \\
\hline & & & $(0.0758)$ & & $(0.0765)$ & \\
\hline \multirow[t]{2}{*}{ PPP per capita (USD/year, scaled) } & & & & & -0.0047 & \\
\hline & & & & & $(0.0572)$ & \\
\hline \multirow[t]{2}{*}{$\begin{array}{l}\text { Total Agriculture Imp World LN(USD1000, } \\
\text { scaled) }\end{array}$} & & & & & -0.1128 & $\star \star \star$ \\
\hline & & & & & $(0.0347)$ & \\
\hline \multirow[t]{2}{*}{ Share of soybean/ agr. Imports (ratio) } & & & & & 0.2982 & \\
\hline & & & & & $(0.5323)$ & \\
\hline \multirow[t]{2}{*}{ Constant } & 0.4771 & $* * *$ & 0.6351 & $* * *$ & 0.5630 & $* * *$ \\
\hline & $(0.0472)$ & & $(0.1045)$ & & $(0.1101)$ & \\
\hline$\sigma_{\mu}$ & 0.3142 & & 0.3131 & & 0.3029 & \\
\hline$\sigma_{e}$ & 0.2276 & & 0.2228 & & 0.2193 & \\
\hline$\rho$ (fraction of variation due to $\mu_{i}$ ) & 0.6560 & & 0.6638 & & 0.6561 & \\
\hline Wald $\chi^{2}$ & 61.65 & & 68.95 & & 156.55 & \\
\hline Prob. $>\chi^{2}$ & 0.0000 & & 0.0000 & & 0.0000 & \\
\hline
\end{tabular}

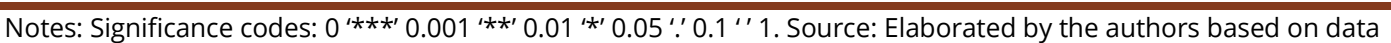
from Faostat, USDA reports and World Bank. 


\section{Final remarks}

In this paper, we analyzed how international trade in soybeans responded to GMO introduction into market chains, mainly focusing on price adjustments in the dual-market system. The analysis consisted of PCA, HCA and a random effects model for panel data. Results from exploratory methods suggested that Brazil propelled a move toward specialization in supplying high-income countries even before the first commercial release of GM-soybeans, although this specialization intensified between 1996 and 2004, when the country could be considered as a GM-Free supplier. Additionally, the high-income countries were those markets that developed high levels of aversion to GMO and/or adopted mandatory labeling policies earlier. However, after rapid pace of technology adoption in Brazil, the "Anti-GMO Markets" were somehow shared by the US and Brazil. The PCA and HCA results strengthen the assumption that Brazil has chiefly supplied markets under mandatory labeling regimes, but evidences to affirm that Brazil managed to trade with higher prices in those markets are weak from the macro-level perspective. The results from the random effects model corroborate the hypothesis that Brazil gained market shares in markets under mandatory labeling regimes as well as allows us to reject the hypothesis of premiums based on aggregated data.

Further studies are required to better assess impacts of new technologies with "hatred" on market adjustments. Studies focused on other grains and technologies under the same market conditions, i.e. a trade-off between adoption benefits for producers and consumer skepticism, are central to understand if and how dual-markets system evolves. As it stands to reason, better understanding the relationship between technological change and trade is central to better design trade policies. Last but not least, finds in this paper can be applied to other agricultural innovations that may have backwards effects on trade due to technology hatred and absence of effective multilateral regulation on approval and other issues.

\section{References}

Berthou, A., \& Emlinger, C. (2011). The trade unit values database. Inter Economics, 128, 97-117. http://dx.doi.org/10.1016/S2110-7017(13)60005-0

Bullock, D. S., \& Desquilbet, M. (2002). The Economics of Non-GMO Segregation and Identity Preservation. Food Policy, 27(1), 81-99.

http://linkinghub.elsevier.com/retrieve/pii/S0306919202000040 http://dx.doi.org/10.1016/S03069192(02)00004-0

Cattell, R. B. (1966). The scree test for the number of factors. Multivariate Behavioral Research, 1(2), 245 276.

Choi, E. K. (2010). International trade in genetically modified products. International Review of Economics \& Finance, 19(3), 383-391. http://dx.doi.org/10.1016/j.iref.2009.04.002

Desquilbet, M., \& Bullock, D. S. (2009). Who pays the costs of Non-GMO segregation and identity preservation? American Journal of Agricultural Economics, 91(3), 656-672. http://dx.doi.org/10.1111/j.1467-8276.2009.01262.x

Everitt, B., \& Hothorn, T. (2011). An Introduction to applied multivariate analysis with R. New York: Springer. http://dx.doi.org/10.1007/978-1-4419-9650-3.

Faria, R. N., \& Wieck, C. (2015). Empirical evidence on the trade impact of asynchronous regulatory approval of new GMO events. Food Policy, 53, 22-32. http://dx.doi.org/10.1016/j.foodpol.2015.03.005

Food and Agriculture Organization of the United Nations - FAO. (2013). FAOSTAT. Rome: FAO. Retrieved in 2019, June 2, from http://faostat.fao.org/site/406/default.aspx

Foster, M. (2010). Evidence of price premiums for non-GM grains in world markets. Australia: Australian Agricultural and Resource Economics Society.

Goodall, C., \& Jolliffe, I. T. (1988). Principal component analysis. Technometrics, 30(3), 351-352. http://dx.doi.org/10.1080/00401706.1988.10488412

Henseler, M., Piot-Lepetit, I., Ferrari, E., Mellado, A. G., Banse, M., Grethe, H., Parisi, C., \& Hélaine, S. (2013). On the asynchronous approvals of GM crops: potential market impacts of a trade disruption of EU soy imports. Food Policy, 41, 166-176.

http://dx.doi.org/10.1016/j.foodpol.2013.05.005 
James, C. (2013). Global status of commercialized biotech/GM crops: 2010 (ISAAA Brief, No. 46). Ithaca: ISAAA.

Johnson, R. A., \& Wichern, D. W. (2002). Applied multivariate statistical analysis (6th ed.). New Jersey: Prentice Hall.

Jolliffe, I. T. (1972). Discarding variables in a principal component analysis. I: artificial data. Journal of the Royal Statistical Society. Series A (General), 21(2), 160-173.

Kaiser, H. F. (1960). The application of electronic computers to factor analysis. Educational and Psychological Measurement, 20(1), 141-151.

Lê, S., Josse, J., \& Husson, F. (2008). FactoMineR: an R package for multivariate analysis. Journal of Statistical Software, 25(1), 1-18. Retrieved in 2019, June 2, from http://www.jstatsoft.org/v25/i01

Lence, S. H., \& Hayes, D. J. (2001). Response to an asymmetric demand for attributes: an application to the market for genetically modified crops (No. 92). Kansas: Kansas State University.

Maechler, M., Rousseeuw, P., Struyf, A., Hubert, M., \& Hornik, K. (2012). Cluster: cluster analysis basics and extensions. Vienna: R Foundation for Statistical Computing.

Oliveira, A. L. R., Silveira, J. M. F. J., \& Alvim, A. M. (2012). Cartagena protocol, biosafety and grain segregation: the effects on the soybean logistics in Brazil. Journal of Agricultural Research and Development, 2(1), 17-30.

Parcell, J. L., \& Kalaitzandonakes, N. G. (2004). Do agricultural commodity prices respond to bans against bioengineered crops? Canadian Journal of Agricultural Economics, 52(2), 201-209. http://dx.doi.org/10.1111/j.1744-7976.2004.tb00102.x

R Core Team. (2012). R: a language and environment for statistical computing. Vienna: R Foundation for Statistical Computing. Retrieved in 2019, June 2, from http://www.r-project.org/

Revelle, W. (2013). Psych: procedures for psychological, psychometric, and personality research. Evanston: $\mathrm{R}$ Foundation for Statistical Computing. Retrieved in 2019, June 2, from http://cran.rproject.org/package=psych

Tillie, P., \& Rodríguez-Cerezo, E. (2015). Markets for non-genetically modified, identity-preserved soybean in the EU (JRC Scientific and Policy Reports). Seville: European Commission. http://dx.doi.org/10.2791/949110.

Ward Junior, J. H. (1963). Hierarchical grouping to optimize an objective function. Journal of the American Statistical Association, 58(301), 236-244.

Wooldridge, J. M. (2010). Econometric analysis of cross section and panel data. Cambridge: MIT Press. Retrieved in 2019, June 2, from http://www.amazon.com/Econometric-Analysis-Cross-SectionPanel/dp/0262232588

Data de submissão: 5 de agosto de 2016

Data de aceite: 22 de dezembro de 2018

Classificação JEL: F13, F14. 